\title{
The Historic Urban Core of Antakya under the Influence of the French Mandate, and Turkish Republican Urban Conservation and Development Activities
}

\author{
Fransız Mandası ile Türkiye Cumhuriyeti Dönemi \\ Kentsel Koruma ve Imâr Faaliyetlerinin \\ Antakya Tarihi Kent Dokusuna Etkileri
}

\section{Mert Nezih RiFAiOĞLU}

\begin{abstract}
Antakya, known as Antioch during the ancient period, is significant among Turkey's historical urban contexts. It is located in the southeast of Turkey, near the Syrian border and is the capital of Hatay province. Called the 'Queen of the East' at one time, it is an important city historically since it was an early center of Christianity and one of the capital cities of the Roman Empire. As a result of its importance, the city has been formed/re-formed over time by different empires, and many structures from various periods are still persist in the current urban form. The aim of this paper is to examine the French Mandate and Turkish Republican Period urban conservation and development strategies in Antakya in order to better understand their influences and effects on its historical urban core. The paper thus begins with an introduction and brief outline of the historical development of the core of Antakya. The second part focuses on the French Mandate and Turkish Republican Period urban conservation and development plan strategies. The final part discusses the effects of different urban development strategies on the historic core of the city.
\end{abstract}

\section{ÖZET}

Antakya tarihi kent dokusu Helenistik dönemden günümüze birçok medeniyet tarafindan iskân edilmiş çok katmanlı bir yerleşimdir. Roma Dönemi'nde Doğu'nun Kraliçesi olarak isimlendirilen Antakya, farklı medeniyetlerin uyguladığı imâr faaliyetleri ile biçimlenmiştir. Bu çalışmanın amacı, Antakya tarihi kent dokusuna yönelik Fransız Mandası ve Türkiye Cumhuriyeti dönemlerinde hazırlanan, uygulanan kentsel koruma ve imâr faaliyetlerinin kentsel dokuya olan etkilerini ortaya çıkarmaktır. Çalışmanın ilk etabını Antakya'nın genel durumu ve kısa tarihçesi oluşturmaktadır. Íkinci bölüm, Fransız Mandası dönemi ile Türkiye Cumhuriyeti döneminde Antakya tarihi kent dokusuna yönelik hazırlanan, uygulanan kentsel koruma ve imâr faaliyetlerine odaklanmaktadır. Çalışmanın son bölümü, kentsel koruma ve imâr faaliyetlerinin Antakya tarihi kent dokusuna etkileri tartışılmaktadır.

Mustafa Kemal University, Faculty of Architecture, Department of Architecture, Antakya, Turkey.

Mustafa Kemal Üniversitesi, Mimarlık Fakültesi, Mimarlık Bölümü, Antakya.

Article arrival date: February 09, 2014 (Başvuru tarihi: 09 Şubat 2014) - Accepted for publication: May 03, 2014 (Kabul tarihi: 03 Mayıs 2014)

Correspondence (iletişim): Mert Nezih RiFAiOĞLU. e-mail (e-posta): mertnezih@gmail.com

๑ 2014 Yıldız Teknik Üniversitesi Mimarlık Fakültesi - @ 2014 Yıldız Technical University, Faculty of Architecture 
A ntakya (Antioch), the capital of Hatay province, is located in the South-Eastern part of Turkey, $25 \mathrm{~km}$ east of the Mediterranean Sea and 20 $\mathrm{km}$ northwest of the Syrian border at an altitude of $80 \mathrm{~m}$. The city is surrounded by Mount Amanos (Nur Mountains) to the north, Mount Kel (Cebel-i Akra) to the south, Mount Habib Neccar (Silpius Mountain) to the east and the Amik plain to the north-east; with the Eastern Mediterranean Sea lying to the south-west of the city. The city is located beside the Asi (Orontes) River which flows into Antakya, with $2 \mathrm{~km}$ of its route lying within the city boundary at a width of 30-35 m. Additionally, the city is located close to such archaeological sites as Tell Tayinat and Tell Açana (Alalah) to the north-east and Seleucia Pieria (Samandağ) to the south-west.

The settled area of the city is divided into two subcity areas by the Asi River. The western part of the city dates back to after the mid-19th century, and is linked to the eastern part over the river by seven vehicular and pedestrian bridges. The western part has main road access to iskenderun (Alexandretta) and Samandağ (Seleucia Pieria). The eastern part contains both the historic urban core of the city, known as 'Old Antakya,' and new areas that developed especially after the first quarter of the 20th century. It has road access to Aleppo, Reyhanlı and Harbiye (Daphne) (Fig. 1).

\section{Brief Historical Development of Antakya (Antioch)}

The city of Antioch ${ }^{1}$ was founded in 300 B.C. by one of Alexander's most able generals, namely Seleucus Nicator 1, in Syria by the River Orontes ${ }^{2}$ on the west declivity of Mount Silpius ${ }^{3}$ near the Lake of Antioch. The River Orontes 'ceased to be navigable for large ships $^{\prime 4}$ in the early middle Ages. The Lake of Antioch

\footnotetext{
The origin of the name of the city differs according to different sources. Some sources claim that the name 'Antioch' comes from Seleucus Nicator's father's name, while others suggest that it was named after his son. Additionally, the name of the city changes in different sources too, being referred to as 'Antioch the Great'; 'Antioch on the Orontes'; 'Antioch of Syria'; and 'Antioch by Daphne'. Commonly, the name Antioch is used for the period between 300 B.C. and 528 A.D. by scholars (Bouchier, E.S., 1921); and so, the name Antioch is used until the end of the Crusader Period, after which, according to the historical developments, Antakie or Antakya are used.

Axius, River of Macedonia, Dra-
} the name of the city and the River Orontes, Silpius is used up until the Mamluk Period, after which Mount Habib Neccar is used.

E.S. Bouchier, A Short History of Antioch, 300 B.C. - A.D. 1268 (Blackwell, Oxford, 1921), p.3.

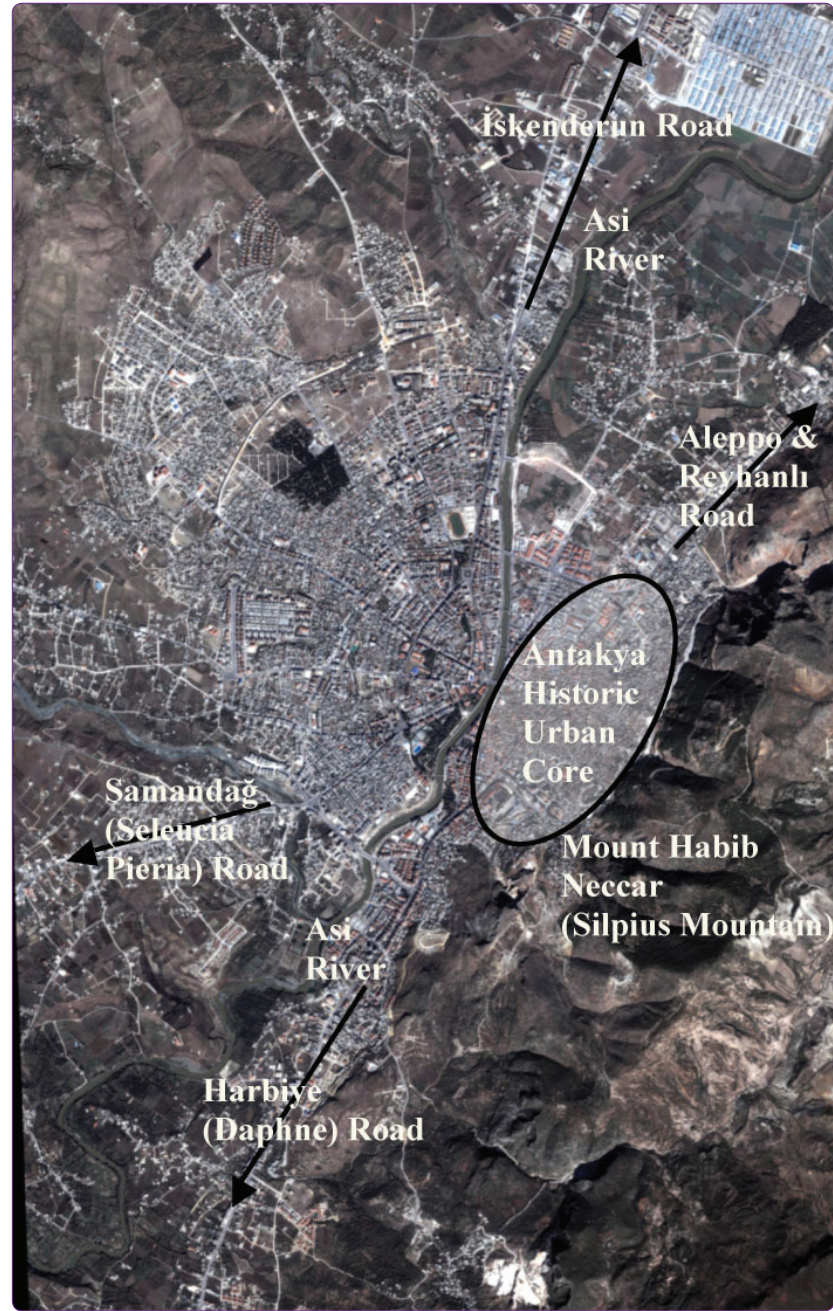

Figure 1. Satellite view of Antakya, 2009 (Source: Antakya Municipality).

was an incredible source of alluvial soil and fish, while Mount Silpius was an important geographical feature that rose to nearly 440 metres above sea level. Both afforded great geographical, economic and strategic importance to the city.

The city was designed as a Hippodamian plan, with straight streets intersecting at right angles, applied by the architect Xenarius. The streets that lie roughly parallel to the Orontes River were laid out 112 metres apart, and the streets intersecting at rights angles to the those streets were 56 metres apart (Fig. 2). This 1:2 ratio in the street layout was typical for Seleucid cities in Syria and Mesopotamia. ${ }^{5}$

In contrast to the precise information on the street layout of the city, there is, unfortunately, no clear in-
A. Demir, Through the Ages Antakya (Akbank Publications, İstanbul,
1996). P. Pinon, 'Survivances Et Transformations Dans La Topographie
D’Antioche Apres L'Antiquite'. Topoi, Suppl. 5 (2004), pp. 191-219. 


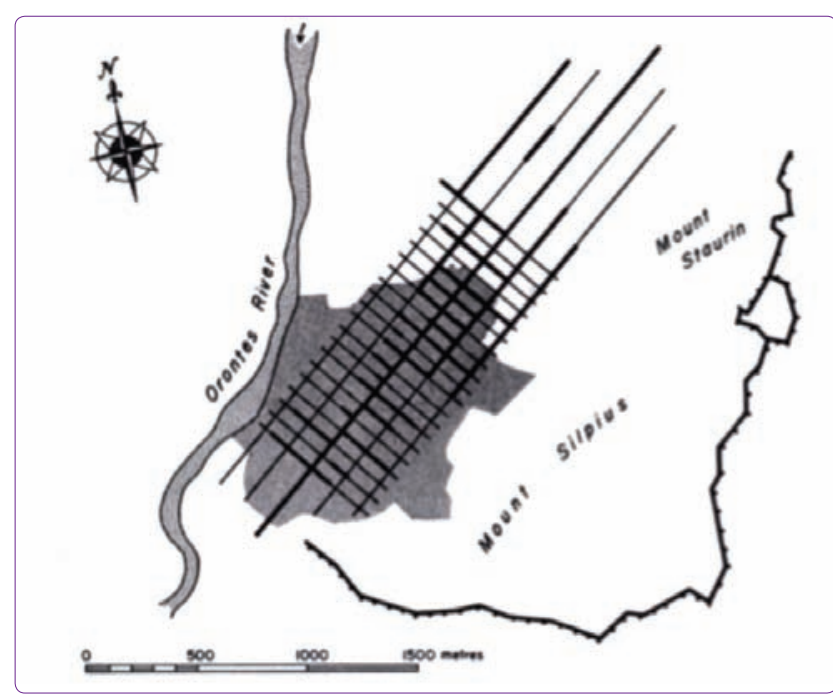

Figure 2. The Hippodamian plan applied by the Seleucid Empire (Source: Downey, G., 1963).

formation on the development activities in the Seleucus 1 Nicator period (312-280 BC). According to previous literature, the city walls enclosed an irregular rectangle consisting of two quarters to the north-west and south-east, and a $160 \mathrm{m \times 147} \mathrm{m}$ agora ${ }^{6}$ was built near the Orontes River to the north-west of the city. In addition, according to the needs of the Hellenistic cites, there would have been a temple to Zeus, a public bath, a palace, public buildings around the agora, a theatre, and aqueducts from nearby water sources.

After the city became a capital, development activities increased under the rule of Seleucus II Callinicus, Antiochus III, Seleucus IV Philopator and Antiochus IV Epiphanes. In that period, the settlement extended over the island in the Orontes River to the west of the city, where a library, public buildings, a bouleuterion, a new agora and several temples were built, and a new urban quarter, named Epiphania, was formed to the south-east. ${ }^{7}$

During the Roman Period (64-395AD), Antioch became the capital of the Empire's Syrian province. The earliest development activities included the building of a palace, a tetrapilon and a circus on the Orontes River Island in $67 \mathrm{BC}$. The island was connected to the city by bridges, one of which was later given a roof. Following that, a temple, the Caisarion, an amphitheatre, an aqueduct and public baths were built. ${ }^{8}$ The grid plan was improved and the colonnaded Herod

6 A. Demir, Through the Ages Antakya (Akbank Publications, İstanbul, 1996), p. 27.

7 G. Downey, A History of Antioch in Syria: From Seleucus to the
Arab Conquest (Princeton University Press, 1961).

A. Demir, Through the Ages Antakya (Akbank Publications, İstanbul, 1996). and Tiberius Street, two Roman miles long (1 Roman mile $=1,478$ metres) was built, covered with marble and lined with bronze sculptures and mosaics. ${ }^{9} \mathrm{New}$ districts were developed to the east and west of the colonnaded street.

At the beginning of Byzantine Period (395-638), when the city was ruled by Theodosius II (408-450), the city walls were extended by one Roman mile to the south to enclose the expanding suburbs of Antioch; a new gate was constructed in the new city wall facing in the direction of Daphne, known as the Golden Gate. Outside the gate, a Christian cemetery was established. During the Byzantine Period, several aqueducts, one reservoir, a stoa, several basilicas and the Church of St. Ignatius, dedicated to the bishop of Antioch, were built. ${ }^{10}$

During the Arab Period (638-968), Antioch was faced a transformation in political, religious and economical aspects and had a minor important despite its importance of the previous empires. ${ }^{11}$

Antioch was regained by Byzantine Empire on 28 October 968. Immediately, the restoration facilities were began in order to revive the past glory of religiously most important Empire's metropolitan city of the Middle East. From the beginning, the city gates and the fortification walls were restored and renewed with four hundred arrow towers. ${ }^{12}$

During the Seljuk Period (1085-1098), churches converted into mosques and one bath was constructed. In this period, Antioch had faced with an extensive earthquake in 1091 which destroyed the city walls, and the houses of the city.

During the Crusader Period (1098-1268), the city of Antioch had been centre of the silk production and fine fabrics which was woven in Antioch especially in Seleucia Pieria and Daphne regions. These fabrics and the products of the silk were exported to the Europe from the Alexandretta port.

During the Memluks period (1268-1516), Antakie had started to lose its religious, economic, and political importance as much as in Christian era. European traders were shifted to particularly Aleppo and the centre of Orthodox churches of Syria was moved to Damascus. Several mosques, madrasas, tombs, imarets, zaviyes, and monuments were constructed and some of

\footnotetext{
9 G. Downey, Ancient Antioch (Prin- ${ }^{11}$ A.F. Türkmen, Mufassal Hatay ceton University, 1963).

${ }^{10}$ E.S. Bouchier, A Short History of Antioch, 300 B.C. - A.D. 1268 (Blackwell, Oxford, 1921)
} 


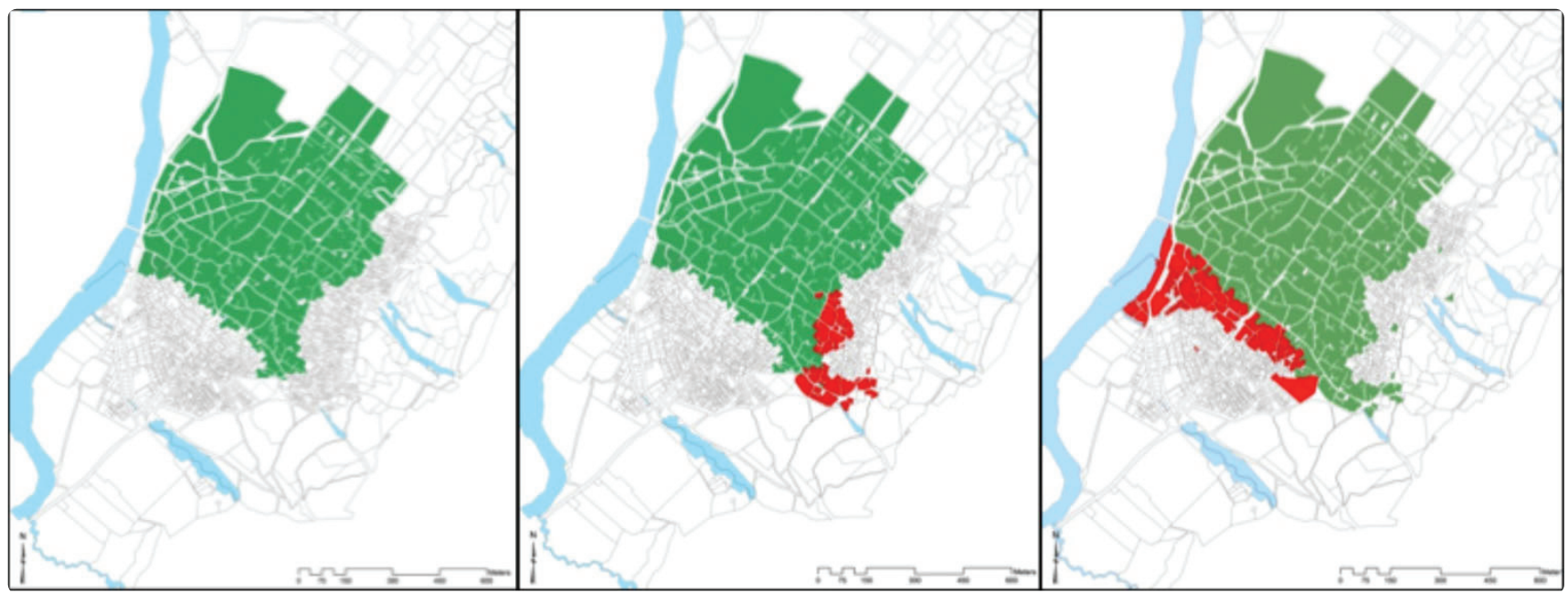

Figure 3. The development phases of urban form between 16th - 18th century. (Thematic maps created according to the relations with literature and the urban form by Rifaioğlu, M.N., 2014).

the watermills (Naura) on the Asi River were dated in this period.

Antakya was ruled by the Ottoman Empire for four centuries (1516-1918) under the sanjak of Aleppo. At the beginning of this new era, Antakya was an important city, being located on the army routes from the Ottoman capital of Istanbul to the Middle East. After the Ottoman army was conquered in Egypt, the military importance of the city decreased,,$^{13}$ but it retained its significance as a rest stop for travellers on their way to haj in the Middle East. This transformation affected the city's urban form, where several waqfs were established and donated mosques, imarets, khans and baths were built throughout the city.

It is apparent that, the construction activities were focused in the trade zone and in its neighbouring districts, which made up the core of the city. At that time, more than 20 mosques and mesjids were built within the settled area, as well as two more khans; a bath, namely New Bath (1671); and several Nauras, or water mills. The city was largely developed by the newly established waqfs, however development was concentrated within the settled area, and so the expansion of the city towards the western edge of Mount Habib Neccar was limited to two districts during the 17th century (Fig. 3).

During the 18th century the city began to expand towards the south. New mosques were established along Kurtuluş Street (Herod or Collonaded Street in Roman Times), including Sarimiye Mosque in 1718 and Şeyh Muhammed Mosque in 1724, and new districts

\footnotetext{
${ }^{13}$ A.F. Türkmen, Mufassal Hatay (İstanbul Cumhuriyet Matbaası, 1937).
}

were established around them. ${ }^{14}$ According to the tahrir records, there were 900 owned properties and 1,255 rented properties in the city, and the numbers of districts increased, despite the seventeenth century (Fig. 3). ${ }^{15}$

Between 19th and the beginning of 20th century, parallel to the revolutions that had occurred following the Tanzimat reforms in the Ottoman Empire, the city's local administrative units started to draw influence from the West, and Western influences were thus injected into the urban core. The office of the deputy governor (kaymakam) and the government palace were built on the Sultan's land. The Palace Road (Saray Caddesi) was opened, leading from the palace to the Great Mosque; and new buildings, social facilities, restaurants, shops were built along the road, turning the area into a social hub of the city (Fig. 4).

\section{French Mandate Period (1918-1938): Re-Inventing the Western Roots of Antakya}

Following World War I Antakya came under the French mandate of Syria (1918-1938). Although it was a short period, Antakya faced significant changes on both architectural and urban scales.

In March 1920, Halefzade Süreyya Bey became the mayor of Antakya municipality, instigating several important development activities in Antakya. Prior to any development, the French Government conducted an extensive and precise cadastral survey between 1926-

\footnotetext{
${ }^{14}$ M. Tekin, Hatay Tarihi Osmanlı ${ }^{15}$ R. Özdemir, ‘Osmanlı Döneminde Dönemi, Atatürk Kültür Merke- Antakya'nın Fiziki ve Demografik zi Başkanlığı Yayınları (Ankara, Yapısı 1709-1860'. Belleten, 221 2000)
} 


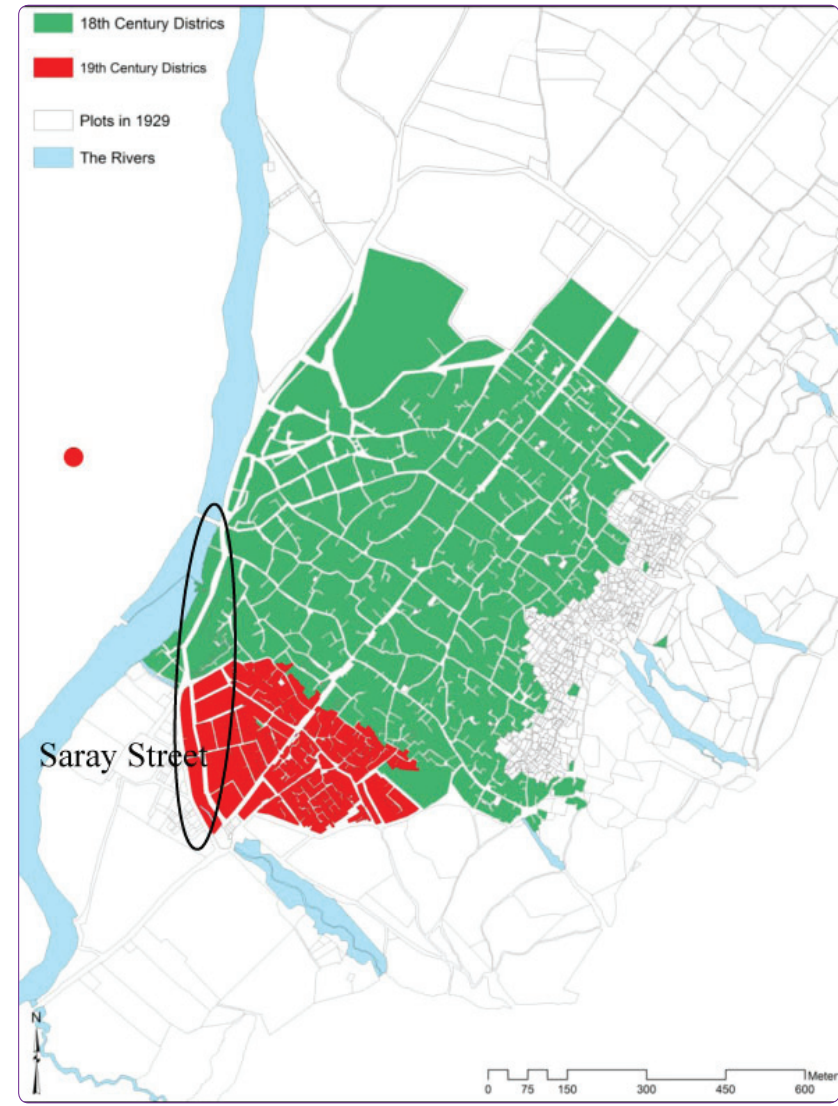

Figure 4. The development of the city from 19th century until the end of the Ottoman period. (Thematic map created according to the relations with literature and the urban form by Rifaioğlu, M.N., 2014).

1929, drawing up 1:500-scale cadastral plans under the direction of Cadastre et d'amélioration fonciére des Etats de Syrie, du Liban et des Alaouites. Accordingly, the title deeds in the city were prepared and updated.

The first important act of Halefzade Süreyya Bey was to sign an agreement between the Antakya Municipality and La Société Antioche Electrique in 1929 that would lead to the provision of electricity to Antakya. ${ }^{16}$ The company built a power plant in the Armutlu district, which was completed in April 1931, and during the construction of the plant electrical installations were made to both public buildings and dwellings. The power plant was activated on 3rd November, with the first recipients of electrical power being Saray Street, followed by public buildings such as the Tourism Hotel; the Governmental Palace; Grande Syria; and the Lebanon Bank, after which private properties were supplied $^{17}$ (Fig. 5).

\footnotetext{
${ }^{16}$ M. Tekin, Antakya Tarihinden Yapraklar ve Halefzade Süreyya Bey (Antakya, 1993), p. 48.
}

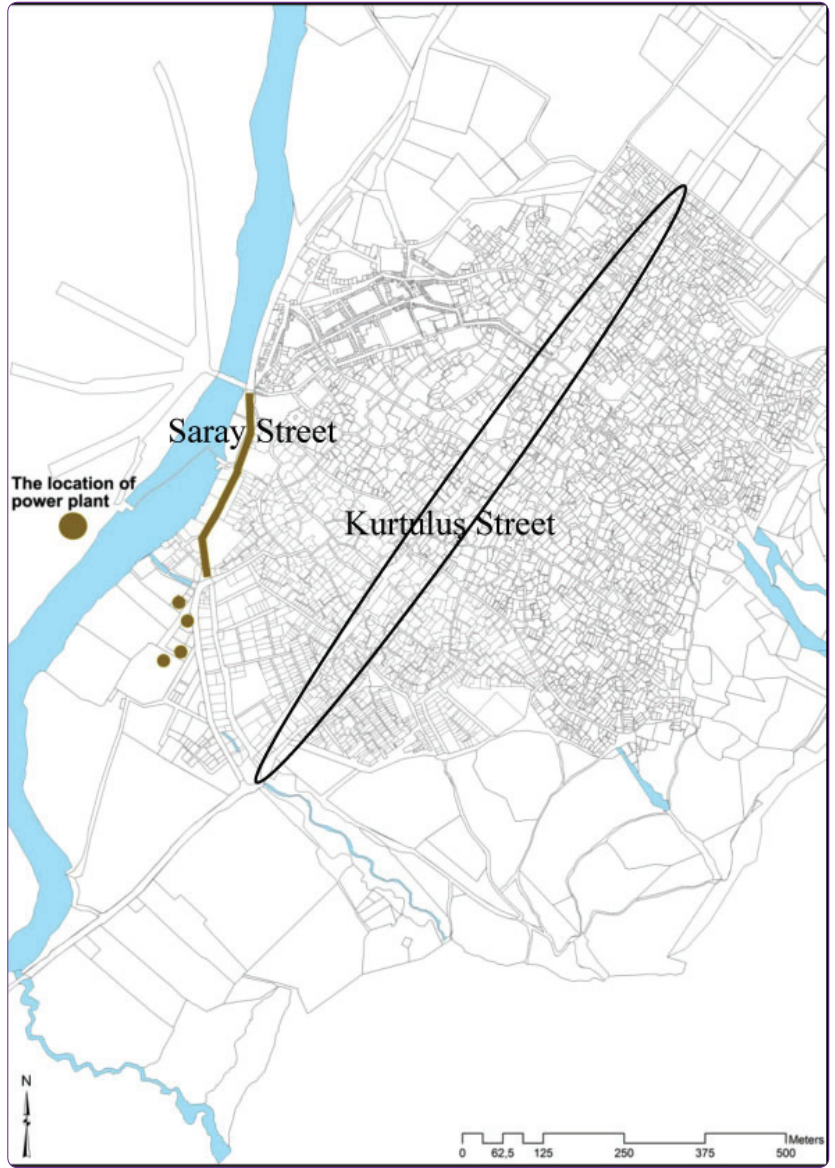

Figure 5. The location of power plant and the first recipients of electrical power which are Saray Street and some public buildings, 1931 (Prepared by Rifaioğlu, M.N., 2014).

Halefzade Süreyya Bey continued making improvements to the infrastructure of the city. In order to solve the water problem of the city, a system was constructed to bring water from the Daphne source, approximately 10 kilometres from the city. It was completed in August 1931, after which the use of wells in private dwellings was prohibited due to their detrimental impacts on health. ${ }^{18}$

Infrastructural improvements continued with the enlarging and/or re-arranging of the Roman Colonnaded Street, namely Herod; Rue Jadid in French Mandate period; and today's Kurtuluş Street. This was an important development activity, since the road was a prestigious urban element dating from the Hellenistic period (Fig. 5).

Works to this end started in 1927 with expropriations and demolitions, and the street was finally opened in 1935 to vehicular and pedestrian traffic. ${ }^{19}$

\footnotetext{
${ }^{18}$ M. Tekin, Antakya Tarihinden Yap- ${ }^{19}$ M. Tekin, Antakya Tarihinden Yapraklar ve Halefzade Süreyya Bey raklar ve Halefzade Süreyya Bey (Antakya, 1993)
} 


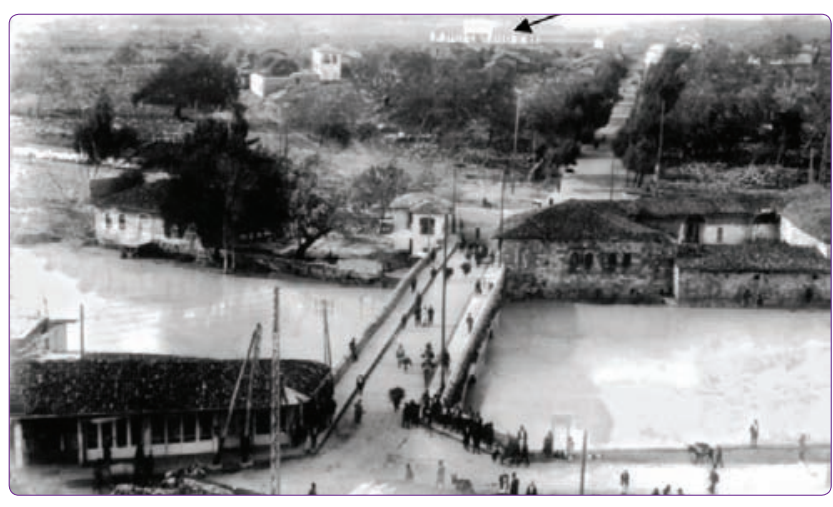

Figure 6. Antakya High School, seen on the left side of the straight axis highlighted by an arrow (Source: Kasım Rifaioğlu personal archive).

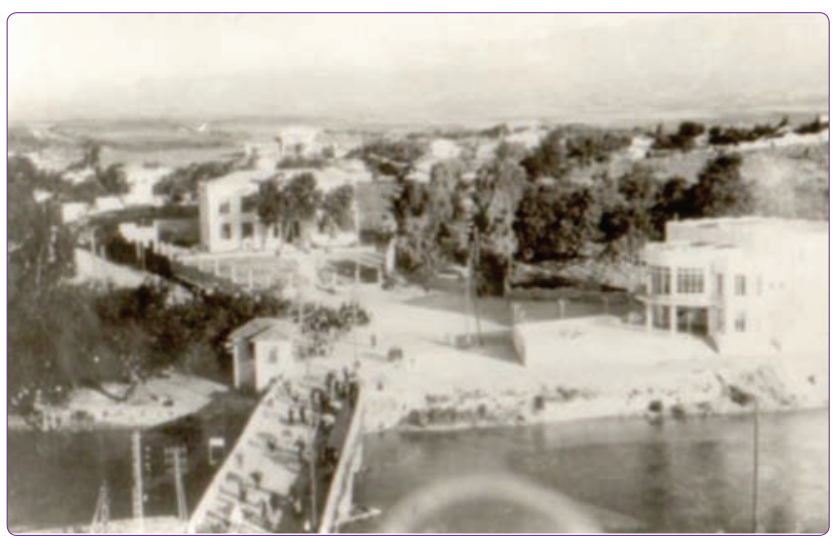

Figure 7. The square, around which can be seen the Municipality building and the Cine Empire on the right (Source: Kasım Rifaioğlu personal archive).

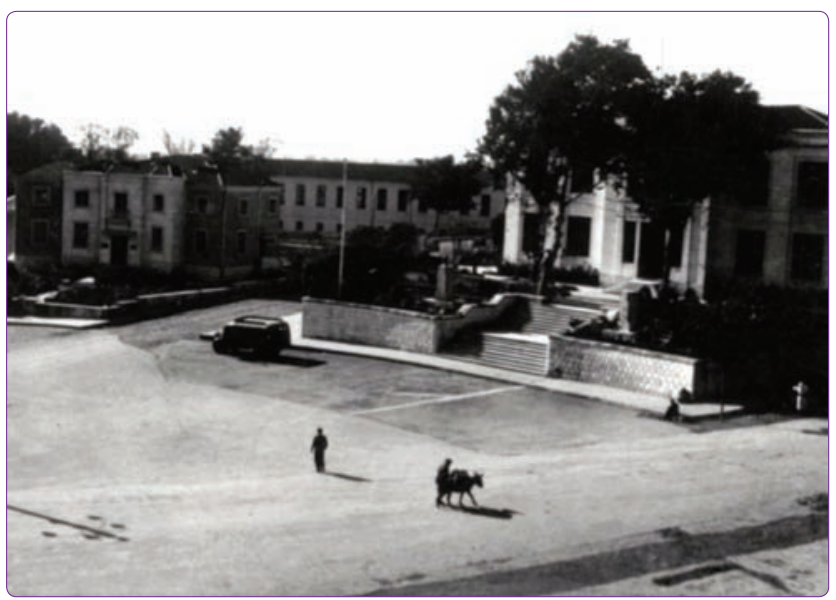

Figure 8. The Municipality building on the right, and the Agricultural Bank on the left (Source: Kasım Rifaioğlu personal archive).

Following the opening of the new street, the new European architectural style was projected onto the facades of the buildings lining the two sides of street, which soon became the location of choice of the bureaucratic elite and rich families of Antakya.

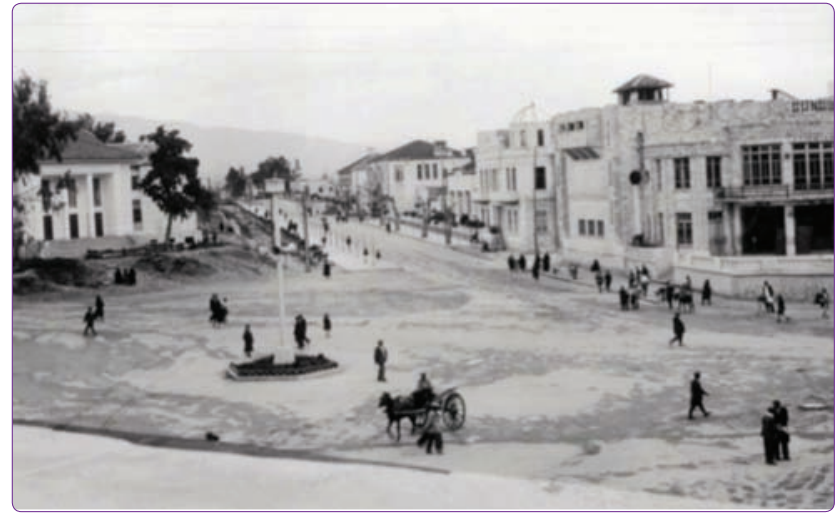

Figure 9. The city development towards İskenderun the private homes of the Adalı family on the right behind the Cine Empire (Source: Kasım Rifaioğlu personal archive).

Besides the infrastructural improvements to the city, a number of important monumental buildings were constructed by the Ministry of Antakya, one of which was a slaughterhouse with modern equipment. Construction started in February 1928 and it was completed in September 1928. Additionally, a hospital was built on the western declivity of Mount Habib Neccar in 1931-1932 with the financial support of the Congrégation des Soeurs de St. Joseph de l'Appatition.

The urban pattern of the historical urban core of Antakya was not well suited to the modern European principles of urbanism. In contrast, the western bank of Asi River was mostly un-occupied, and the vacant lands served as a suitable area for French mandate expression and Western urbanism principles. Large streets, intersecting at oblique or right angles, squares, and Western style monumental buildings were started to be built on the western side of Asi River. ${ }^{20}$ Firstly, the Antakya High School was built by the Georges Moussalem enterprise, designed by M. Kowalski, who was hired by the sanjak ${ }^{21}$ (Fig. 6).

After which a public square was designed at the intersection of the İskenderun (Alexandretta) and Samandağ (Seleusia Priera) roads, linked directly to the Roman Bridge over Asi River. The square was surrounded by such public buildings as municipality, Cine Empire, a bank, a museum and a post office, as well as the private homes of the Adalı family and the Governor respectively (Figs. 7-9).

\footnotetext{
20 i. Aslanoğlu, 'Fransız iş̧gal ve Manda Döneminde İskenderun Sancağı: Kentsel ve Mimari Değişimleriyle İskenderun, Antakya ve Kırıkhan Kazaları'. Papers Submitted to International Symposium Ottoman Heritage in the Middle East, vol. 1, Publication of Atatürk

Culture Center, Ankara, (2000). 1 Ü.F. Açıgöz, A Case in French CoIonial Politics of Architecture and Urbanism: Antioch and Alexandretta During the Mandate, (unpublished Master Thesis, METUFaculty of Architecture, Ankara, 2008).
} 


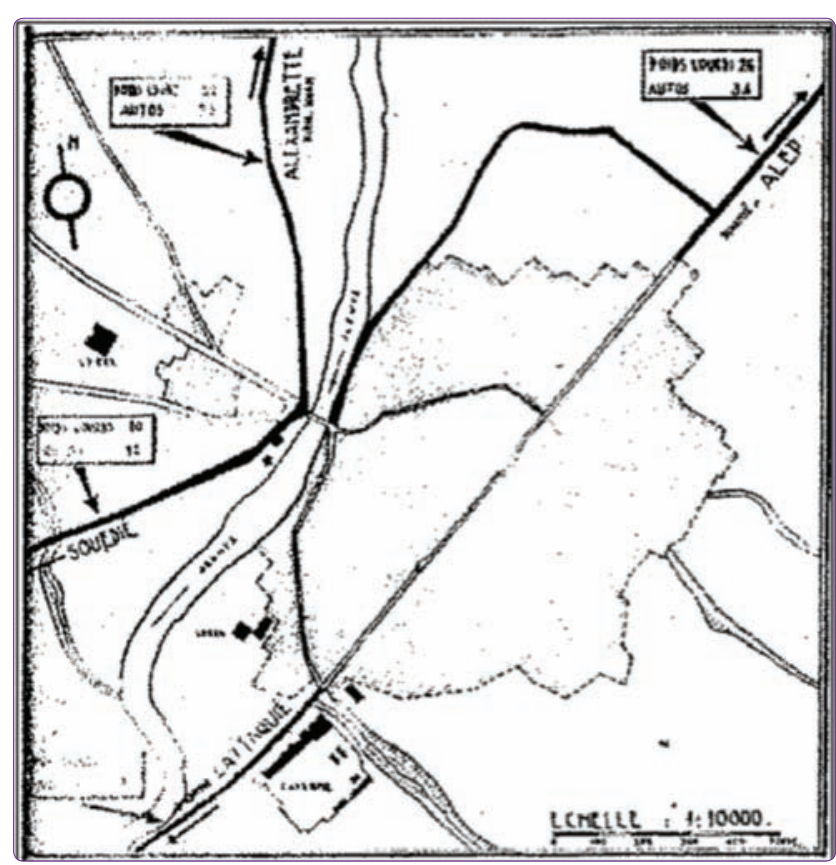

Figure 10. The existing street network of Antakya in 1932 (Source: Pinto, V., 1938)

\section{The first urban development plan of Antakya:} The Danger Plan

Réne Danger, who was the principal city planner of the French Mandate, prepared 1:10.000 urban development plans for Antakya in $1932 .{ }^{22}$ The plan suggested two main developments:

- The development of the road network, and the connection of the western and eastern parts of Asi River via a circular highway

- Functional zonings for the old and new urban pattern of Antakya

For the development of the urban road network, Danger proposed three squares in the nucleus of the city, two of them in the old city in front of the Great Mosque and the Habib Neccar Mosque on Kurtuluş Street; and the other in the new city where the new public buildings had been constructed (Fig. 10). Additionally, the plan widened Saray Street to $15 \mathrm{~m}$. through some expropriations, and connected it to the Daphne road (Fig. 11).

The proposed square in the middle of the historical urban core in front of Habib Neccar Mosque was to be connected to a new street, proposed to run perpendicular to the proposed square in front of Great Mosque (Fig. 9). The rationale behind this decision was that it

22 V. Pinto, L'Evolution de Antioche, son passé, son état actuel, son avenir (un-published Master thesis, Institue d'Urbanisme de Paris, Paris, 1938).

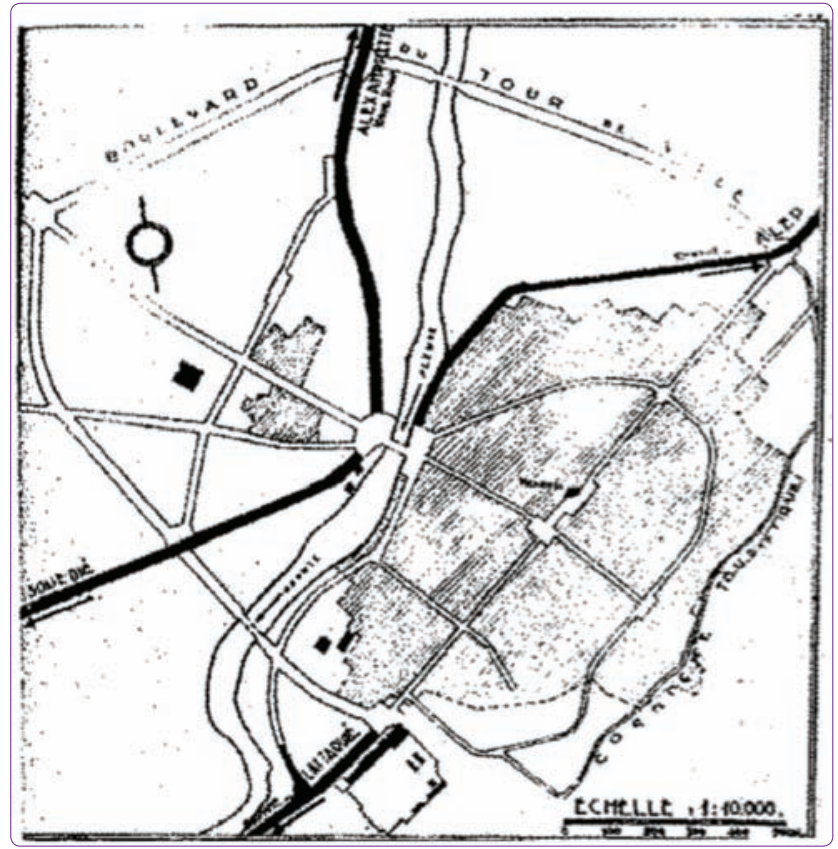

Figure 11. The proposed street network (Source: Pinto, V., 1938).

would re-define the Roman Period Tetrapylon. The plan proposed a circular highway to connect the Aleppo, İskenderun, Samadağ and Daphne roads, including the construction of two more bridges over the Asi River.

The plan also defined functional zones throughout the historical urban core of Antakya, and the new area to be developed on the west bank of Asi River. The plan proposed the creation of a trade zone, industrial zone, residential zone and collective habitation zone in the historical urban core.

The plan was approved by Antakya Municipality, and most of the proposed developments to the west of the Asi River were carried out; however, the plan was only partially implemented in the historical core of the city (Fig. 12).

\section{Urban Development Strategies in French Mandate Period: Tourism, Archaeology and Orientalism}

During the first half of the 20th century, the Middle East attracted many Western scholars and tourists hoping to gain an understanding of the Oriental culture. European visitors first came to countries in North Africa, especially Egypt and Tunisia, and to the Eastern Mediterranean, and a culture of mass tourism started after the founding of Société Oriental de Tourisme in 1930. ${ }^{23}$

\footnotetext{
23 Ü.F. Açıkgöz, A Case in French Colonial Politics of Architecture and Urbanism: Antioch and Alexandretta During the Mandate, (un-published Master Thesis, METU-Faculty of Architecture, Ankara, 2008).
} 


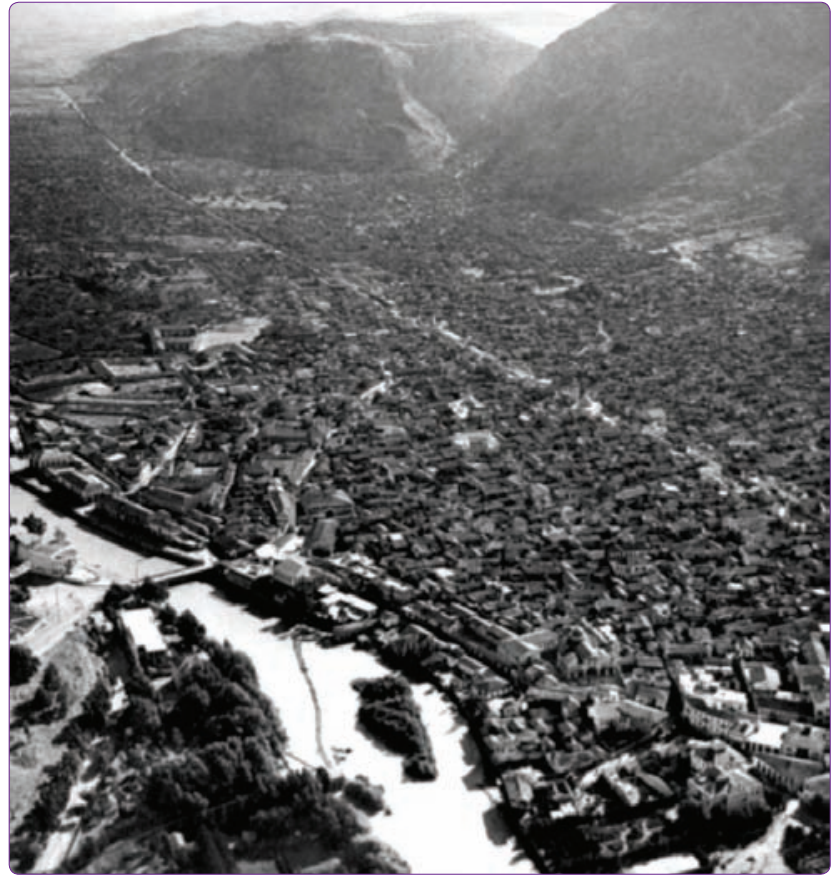

Figure 12. Antakya in the French Mandate Period (Source: Kondoleon, C., 2001, p.2).

The French Mandate gave priority to increasing tourism activities in Syria, particularly in the north of the country, as a geographically and historically important region dating back to the times of the Roman Empire. In 1871, one of France's largest cruise companies, La Compagnie des messageries maritimes, was established and started to organize tours to the Malta, Alexandria, Port Saïd, Beirut, Alexandretta and Syria (Fig. 13).

Initially, it was French visitors that started exploring the Eastern Mediterranean and Oriental culture, and to accommodate them, Hotel Silpius and Hotel du Tourisme opened. Hotel du Tourisme was converted from a neo-classic mansion, managed by Sociéte des Grands Hotels du Levant, which was the responsible body of the French Mandate throughout Syria. ${ }^{24}$

It is well known that Antakya and its environs were an important tourism destination in Syria, based on its rich historical, archaeological and religious backgrounds as one of the holiest place of Christianity, its importance as the eastern capital city of the Roman Empire and the Crusader Kingdom, and its Ottoman urban form. For this reason, the Comité du Tourisme, established in 1930, gave priority to the development and promotion of tourism in Antakya and its surrounding area. To this end, the Comite charged Paul

${ }^{24}$ P. Jacquot, Antioche: Centre de Tourisme, Comite de Tourisme d'Antioche (Antakya, 1931).

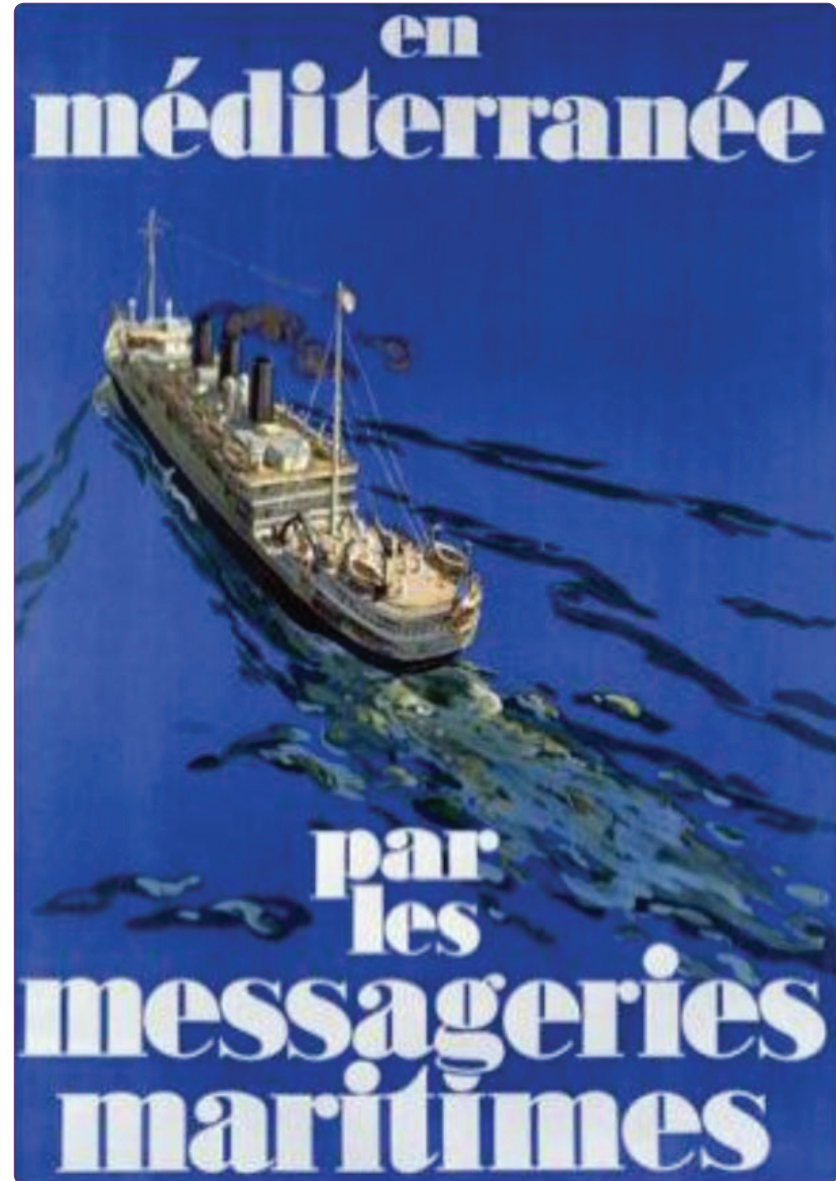

Figure 13. Poster advertising tours of Mediterranean harbours (Source: La Compagnie des messageries maritimes).

Jacquot ${ }^{25}$ with compiling a tourist guide for Antakya, which was published in 1931 in three volumes under the title Antioche, Centre de Tourisme. The book contained extensive information about Antakya and the region stretching from Alexandretta to the Reyhanlı. The history of each town was described in detail, with information on the archaeological edifices and monuments in Antakya. The guide also highlighted French development activities, including those related to public services, investment for commerce, development of infra-structures and super-structures of the city, etc. Accordingly, Antakya became a key destination for French tourists, who came in their droves to the region and intermingles with the city's inhabitants during the French Mandate (Fig. 14). The guide had particular focus on the historical identity of Antakya and its roots in the Roman Empire, while the Comité du Tourisme gave priority to archaeological investigations in order to promote Antakya's touristic potentials.

${ }^{25}$ P. Jacquot, Antioche: Centre de Tourisme, Comite de Tourisme d'Antioche (Antakya, 1931). 


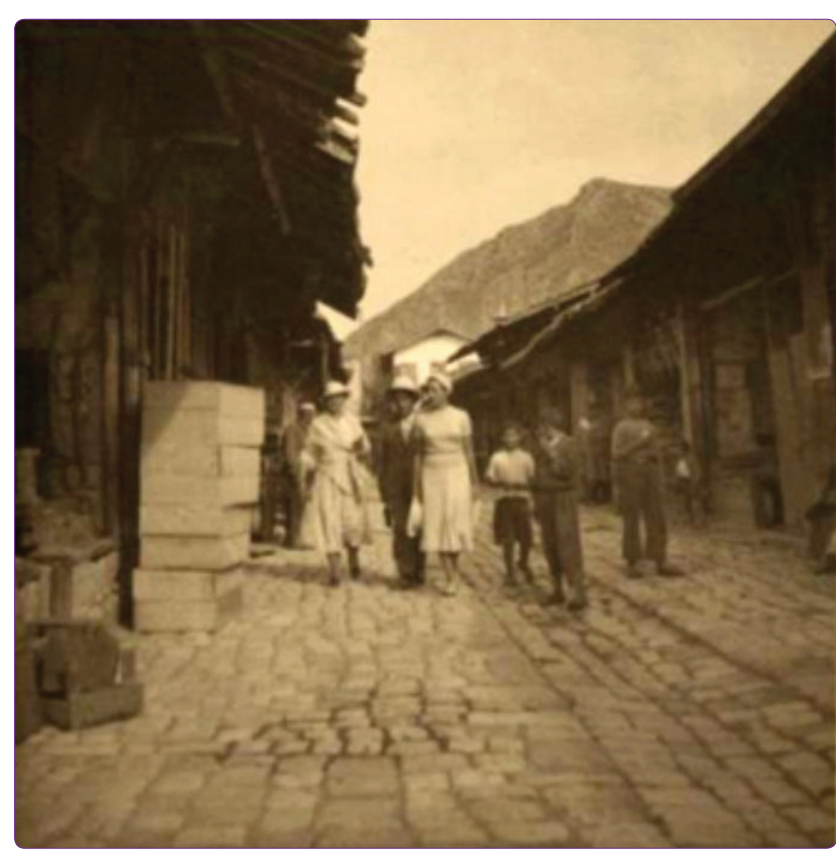

Figure 14. Tourists in the streets of Antakya (Source: Library of Congress).

Accordingly, Services d'antiquités was established, which conducted several excavations throughout Syria and Antakya in collaboration with Institut Français de Damas. In Antakya and its surroundings, several archaeological surveys and excavations were carried out by Princeton University, Louvre Museum and the Chicago Oriental Institute.

The findings made during archaeological excavations in Antakya made it the most important city in regards to Roman and Hellenistic Period artefacts. Consequently, the French Mandate gave utmost priority to excavations and their findings with the intention of re-defining the historical importance of Antakya. In the 1932-1936 periods, 40 excavations were carried out throughout Antakya (Fig. 15).

In parallel to the excavations, the conservation and display of archaeological findings was another important task for the French Mandate. The archaeological findings were initially exhibited at Antioch High School and in the Antakya Municipality building, ${ }^{26}$ however owing to the large quantity of archaeological finds; Service d'Antiquités began considering the construction of a purpose-built museum. Architect Michel Ecochard was appointed to design the museum, and a site was selected on the corner of Public Square to the west of Asi River. The major design concept of the museum

${ }^{26}$ P. Jacquot, Antioche: Centre de Tourisme, Comite de Tourisme d'Antioche (Antakya, 1931).

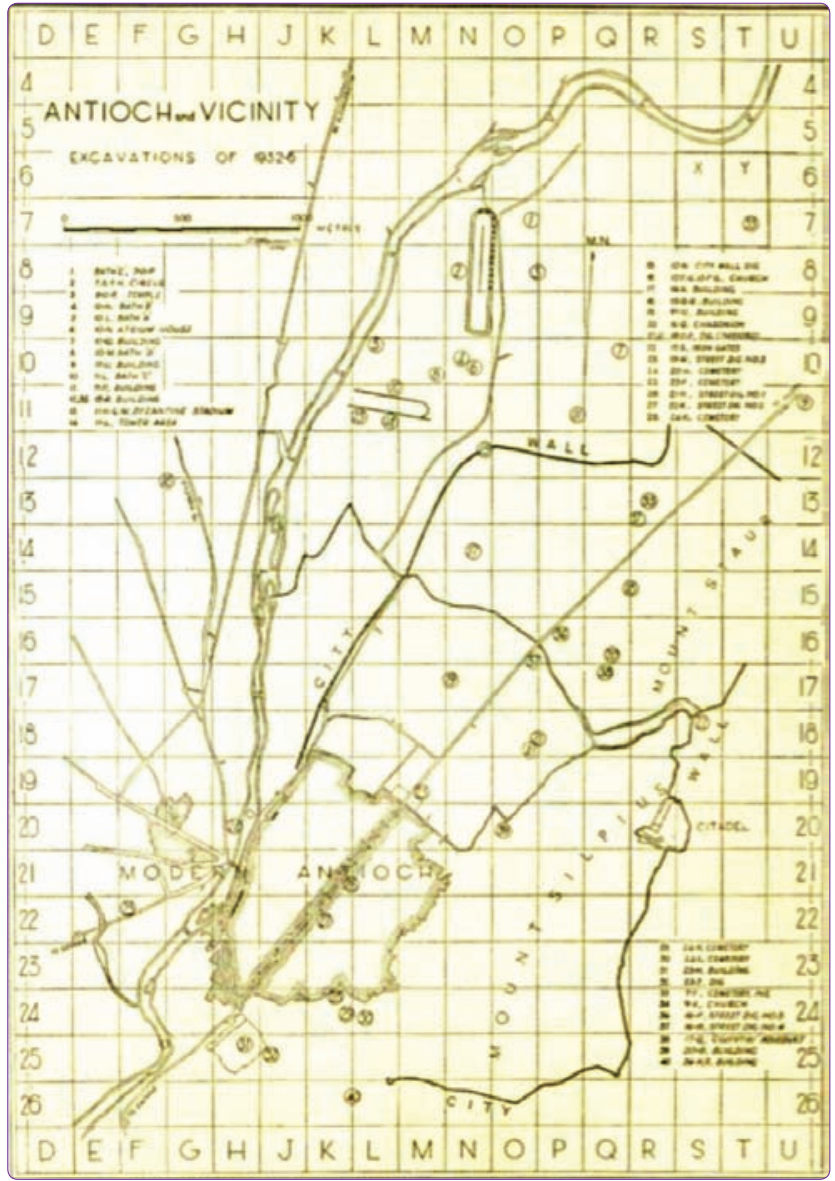

Figure 15. The location of excavations carried out between 1932-1936 in Antakya during the Princeton University Antiokhiea works (Source: Hatay Kültür Envanteri, 2011, p. 25).

was based on housing the large-scale archaeological finds, including the many huge Roman mosaics. The design project was finished in 1933 and construction of the museum began in 1934, and the museum was opened to the public in 1939. An annex entrance was added to the front façade of the building in $1975 .{ }^{27}$

Service d'urbanisme conducted several surveys under the French Mandate to investigate the current urban forms and aspects of the Oriental city form. Urban geographer Jacques Weulersse ${ }^{28}$ conducted a survey of Antakya in an attempt to define its Oriental character, the results of which were published in 1934.

The survey took the form of a morphological analysis of the relationships between the ethnic structure

27 i. Aslanoğlu, 'Fransız İşgal ve Manda Döneminde İskenderun Sancağı: Kentsel ve Mimari Değişimleriyle İskenderun, Antakya ve Kırıkhan Kazaları'. Papers Submitted to International Symposium Ottoman Heritage in the Middle
East, vol. 1, Publication of Atatürk Culture Center, Ankara, (2000).

$28 \mathrm{~J}$. Weulersse, 'Antioche Essai de géographie urbaine', Bulletin d'Etudes Orientales, Tome IV, (1934). 
and the districts; the religious monuments and their surroundings; and the formation of the trade zone and its urban structures. He highlighted the differences between the Roman Antioch and the Islamic urban form with giving references to the urban elements of the grid plan from Roman Antioch. ${ }^{29}$

According to Weulersse, the current city was formed under Islamic urban form principles, and it an important example of a city that was converted from a Roman form to an Islamic urban form. Weulersse stressed that, 'The Islamic rules and regulations were an affective parameter throughout the physical urban fabric, and thus it was strengthened with the land ownership rights of the Ottoman period'. ${ }^{30}$

Weulersse's analysis indicated that there were strict separations throughout the urban form along ethnic, religious and economic lines, characterizing the separate districts and zones. He claimed that this separation was typical of Oriental cities, and defined them as closed urban units. ${ }^{31}$

Weulersse noted that the Christian community was located around the Saray Street, the Sunni Muslims (Turks, using Weulersse's definition) were located in the souq area and the Habib Neccar Mountain, and the Alewites were located on the fringes of the urban core, since they were in the lower income group and carried out labouring work (Fig. 16).

Lastly, Weulersse analyzed the trade zone of the urban form, and the souqs, khans and soap factories (savonnaries). He claimed that the trade zone of Antakya had been influenced directly by the norms of the Islamic urban form, and was formed by religious monuments and trade buildings.

Following the French Mandate Period, Antakya came under the independent Hatay State (1938-1939) which only lasted for one year, and so the city saw no significant physical development, rather only political change. During the period of the Hatay State, the Cine Empire was used as the Hatay Parliament building, and Tayfur Sökmen was elected as the president of the Hatay State. Thereafter, Antakya was unified with the Turkish Republic as the last city to join the new Republic of Turkey.

\section{Turkish Republic Period (since 1939)}

During the early years of the Turkish Republic, Antakya's development faced a contrary with the devel-

\footnotetext{
${ }^{29} \mathrm{~J}$. Weulersse, (1934). Ibid.

${ }^{30} \mathrm{~J}$. Weulersse, 'Antioche Essai de géographie urbaine', Bulletin

d'Etudes Orientales, Tome IV, (1934).p.40.

31 J. Weulersse, (1934). Ibid, p.37.
}

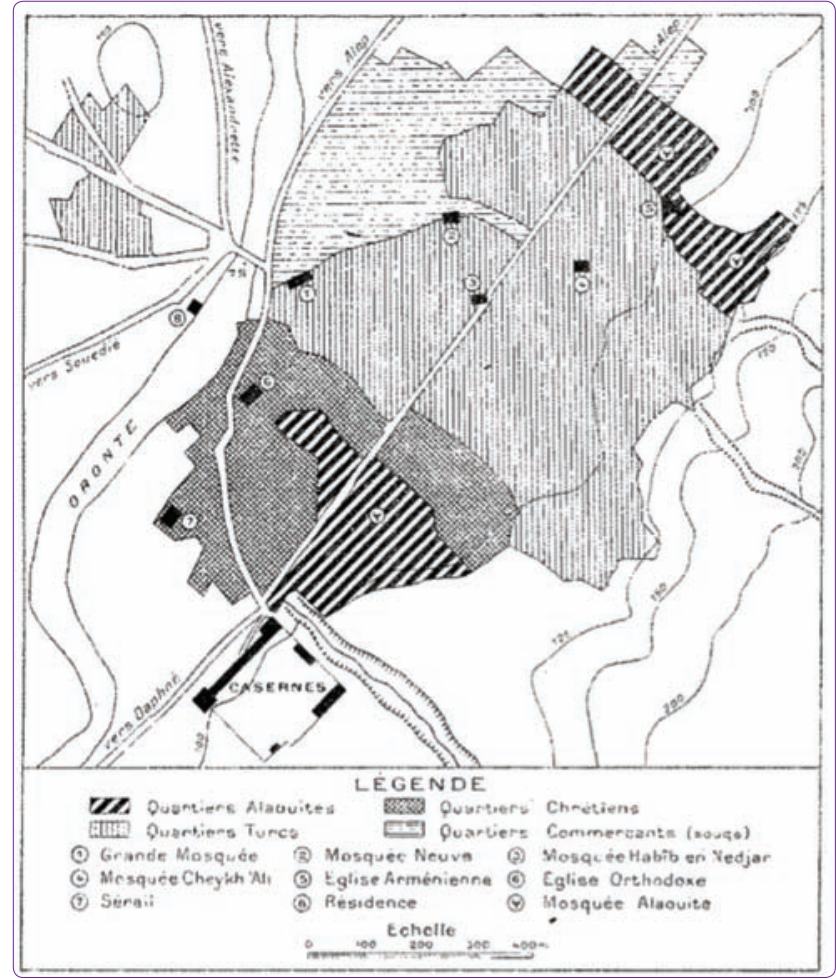

Figure 16. Ethnic and religious quarters of Antakya (Weulersse, 1934, p. 39).

opment activities of new urban areas and the conservation of the historic urban core. The first urban development plan for Antakya was prepared by Asım Kömürcüoğlu on the instruction of the Cities Bank (iller Bankası) of Turkey in 17th May, 1948. However the plan was not implemented and another urban development plan was prepared in 1:5000; 1:1000; and 1:500 scales by Assoc. Prof. Gündüz Özdeş, and approved on 1st January, 1957.

The 1:5000 scale plan showed the current settlement area expanded in a south-west direction from the historical core and centrally spread to the west part of Asi River. The plan appointed new settlement areas in the northern part of the historical trade zone, and in the south part where the military barracks, Christian and Muslim cemeteries had existed since the Ottoman Period. Heavy and light industrial areas were located in the northern part of the historical core, on a site formerly used for orchards and agriculture (Fig. 17).

The plan also proposed an extensive change to the street system of the urban core, with several roads, including Kurtuluş Street, marked for widening to 20 metres and new streets to be established in the core through expropriations within the current urban fabric. The plan also proposed a new road system in the new development area to the west of Asi River, con- 


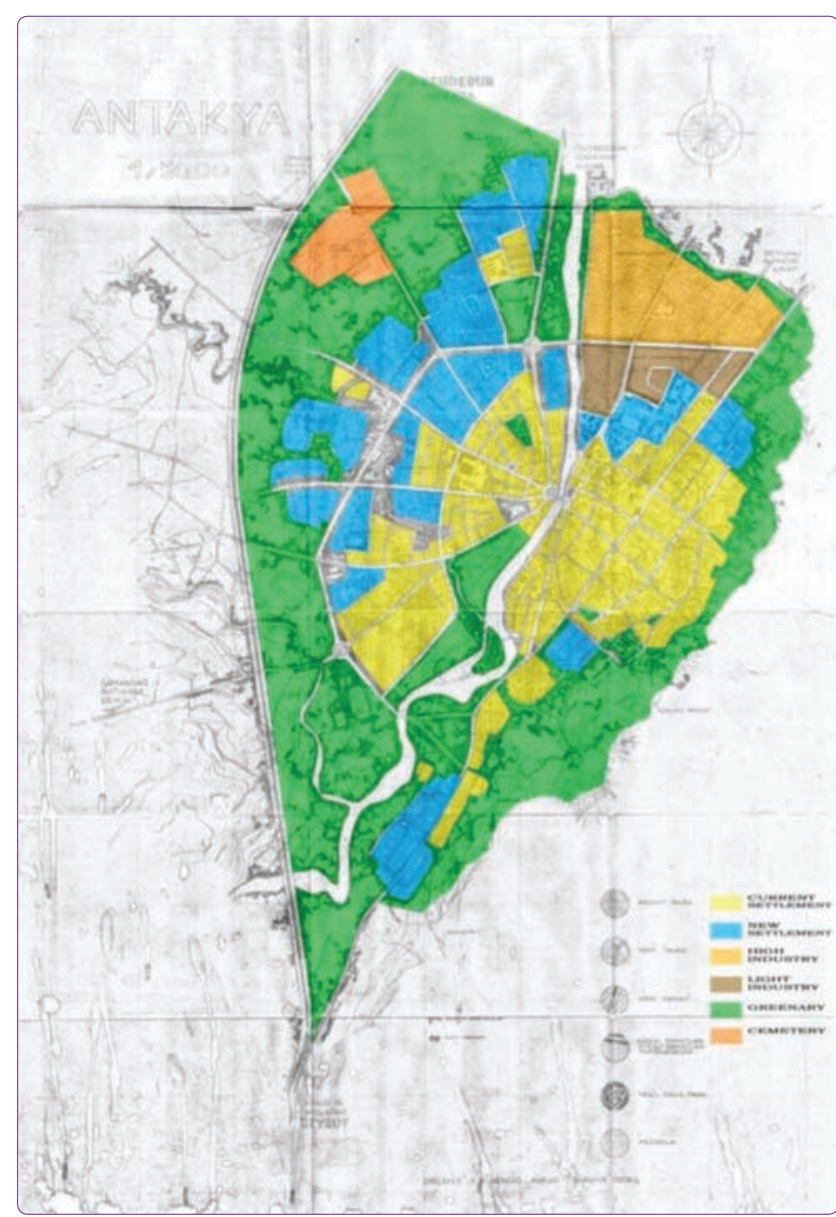

Figure 17. 1/5000 scale Land Use decisions on the urban development plan of Antakya (Reproduced by Rifaioğlu, M.N.2011, after Özdeş, G.).

necting it to the historical core of Antakya. ${ }^{32}$

The main objective of the proposed street layout was to create large building blocks throughout the urban core, and to provide easy vehicular access by eliminating the winding and narrow street layout.

In line with the plan, some decisions were implemented in the historical urban core. Firstly, expropriations were made in the historical trade zone to make room for an inter-city coach terminal, a wholesale fruit and vegetable market, a contemporary open bazaar and office buildings.

Secondly, a road was opened perpendicular to Kurtuluş Street leading towards Asi River, for which many traditional houses were expropriated and demolished. Additionally, expropriations were made around the Great Mosque to clear the way for a new development block and a Republic Square (Fig. 18).

\footnotetext{
${ }^{32}$ G. Özdeş, Antakya Urban Development Plan, (1957).
}

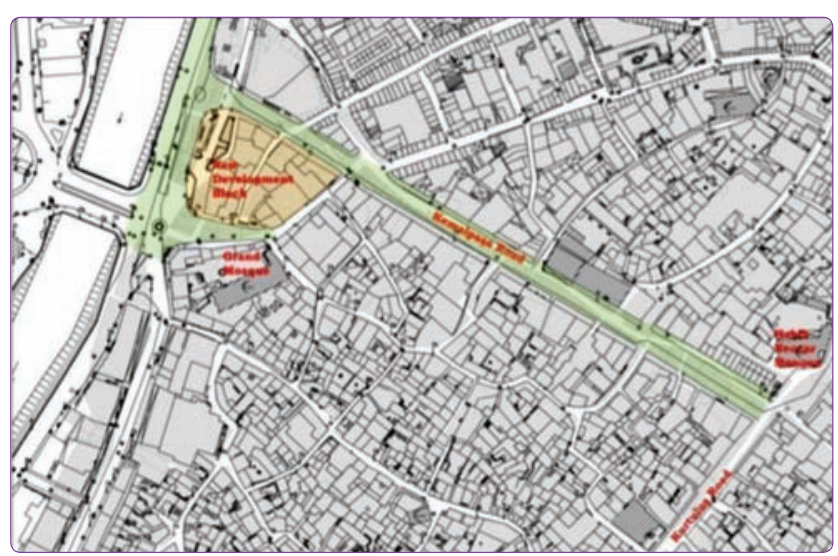

Figure 18. The Kemalpaşa Road and a new development block were built after expropriations. The grey plots showed the location of the former historical urban fabric (Prepared by Rifaioğlu, M.N., 2011).

For the historical urban core itself, the plan did not define any conservation requirements, as the intention was rather to change the traditional urban fabric, and therefore affecting the traditional character which needed to conserve. The plan was followed until 1978, and many expropriations were made within the historical urban core that destroyed the unique physical characteristics of the urban form. The destruction of the 10-metre, 4-arched Roman Bridge ${ }^{33}$ to make way for a reinforced concrete bridge in 1970 was the most striking example of this.

Following these destructions of the historical urban core of Antakya, the High Council of Immovable Old Assets and Monuments (GEEAYK) announced that, 'as a world famous city it is important to conserve all of its values as far as possible for the next generations. Thus, a new development plan should be prepared defining the historical buildings, urban site, archaeological and natural sites according to the 1710 Old Assets Law, from which conservation decisions should be taken'. ${ }^{34}$

Accordingly, in 1975 a site survey was carried out by appointed experts, and the historical buildings in need of conservation, as well as the urban site and the archaeological and natural site boundaries were defined in 1:1000 and 1:5000 scales. According to the survey, 70 buildings were required to be listed as monumental buildings, comprising 24 mosques, six mesjids, two khans, four baths, three tombs, 17 fountains, one covered bazaar (bedesten), two soap factories, two churches, one synagogue and eight other buildings. Additionally, 132 traditional houses were listed. ${ }^{35}$

\footnotetext{
${ }^{33}$ C. O'Connor, Roman Bridges sion number.

(Cambridge University Press, ${ }^{35}$ GEEAYK, Antakya Kültür Envante-

Cambridge, 1993).

${ }^{34}$ GEEAYK, 12 July 1975, 8521 deci-
} 
The regulations to be complied with within the urban site were defined as:

- the façade of the existing street layout should be conserved

- the height and ratio of the built-up area to plot area should be conserved, and the heights and ratios of new buildings should not exceed those of any historical buildings

- the original street layout, street sections and stone coverings should be conserved and repaired as required

- it will not be allowed to cover the streets with asphalt or concrete

- new building constructions within the urban site will only be allowed if they are compatible with the surrounding architectural characteristics

- old and deteriorated historical buildings should be repaired, conserving their architectural characteristics and using original materials as much as possible.

Additionally, the High Council of Immovable Old Assets and Monuments (GEEAYK) set out regulations related to the archaeological site, as defined below:

- the urban development plan now in the process of being prepared must not include any industrial development within the archaeological site

- existing industrial buildings should be relocated in time, and the establishment of new industrial buildings within the archaeological site boundary is prohibited

- public buildings are not allowed to be constructed within the archaeological site

- the construction of new residential buildings is only allowed on plots of more than $2,000 \mathrm{~m}^{2}$ plots if they do not exceeded two storeys in height

- during new residential building constructions, staff from the Archaeology Museum should be on hand during the foundation works of the building in case any archaeological remains are uncovered

- a division of plots is not allowed within the archaeological site.

In addition to those regulations, the High Council of Immovable Old Assets and Monuments pushed for the preparation of an urban conservation and development plan for the historical urban core of Antakya. The presence of many valuable historical buildings and monuments in the core necessitated a deeper survey in order to facilitate the forming of appropriate conservation decisions.

In parallel to the conservation measurements taken in the historical urban core, an urban development plan and an Antakya historical site special development plan (Antakya Tarihi Sit Mevzii Imar Planı) was prepared by Yavuz Taş̧̧ı in 1978 in 1:1000 scale.

In line with the decisions taken by the High Council of Immovable Old Assets and Monuments the plan also defined the boundaries of both the urban and archaeological sites. However, the plan defined a deteriorated urban site where the heavy and light industrial areas existed on the northern part of historical urban core, and so the restrictions defined by the High Council of Immovable Old Assets and Monuments for the industrial area were invalidated.

Consequently, not only did expropriations and plot divisions continue in the industrial area, but also the construction of new industrial buildings rather than two-story residential buildings.

Additionally, the plan contained 1:500-scale urban development application proposals for the historical urban core, proposing new physical interventions and functional proposals for the historical monuments.

In parallel to these activities, the urban conservation and development plan was prepared by Assist. Prof. Dr. Nurcan Uydaş from the Gazi University Faculty of Engineering and Architecture, under assignment to Antakya Municipality, in 1987. While the conservation plan studies were continuing, the listed building records were updated and registered by the High Council of Immovable Old Assets and Monuments in 1982. With this registration, the buildings listed were 24 mosques, seven mescids, four khans, four baths, seven tombs, 20 fountains, one covered bazaar (bedesten), four soap factories, two churches, one synagogue, and 25 other buildings, as well as 269 traditional residential buildings.

The plan and its supplementary documents were approved in January 1987, defining a 1st and 3rd degree archaeological site, a natural site and an urban site.

The plan contained the following regulations (Fig.19):

- a division of plots of less than $300 \mathrm{~m}^{2}$ is not allowed in the 3rd degree archaeological site

- the maximum construction height for non-regis- 


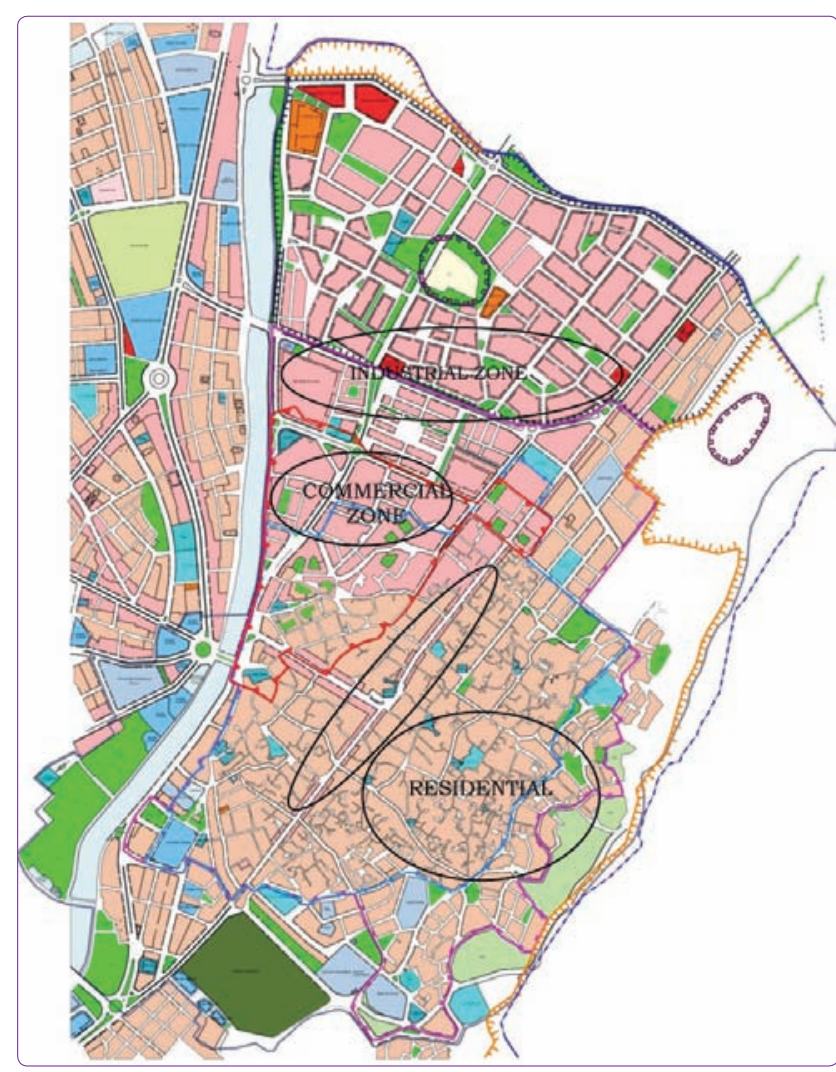

Figure 19. Antakya urban conservation and development plan, 1987 (Source: Antakya Municipality).

tered buildings on Kurtuluş Street is $\mathbf{1 3 . 5 0}$ metres and four storeys, and new buildings should be set 3 metres back from registered buildings

- some streets within the urban site are to be widened to 10 metres and straightened

- the population of the urban site should be constantly conserved

- secondary streets are to be conserved in their original cadastral situation

- street characteristics related to their form, pavement and slopes should be conserved

- registration covers not only the buildings on the plots, but also the gardens and courtyard, and elements such as pools, wells, fountains and other features

- original architectural elements and the form of the facades and buildings should be conserved

- new buildings within the urban site are restricted to a total building area coefficient (TAKS) of maximum 0.5 , a total floor area coefficient of maximum 1.00 (KAKS) and maximum two storeys in height
- the construction of any building more than $120 \mathrm{~m}^{2}$ in plan area on any plot is prohibited.

The plan remained valid for twenty-two years. During that time, as a result of some inappropriate planning decisions and a lack of management and control over the urban conservation, much deterioration occurred within historical urban core that can be grouped under the following aspects: street layout; new architectural elements and buildings; changes to the original owners; population and functional interventions causing deterioration in the traditional materials; and construction techniques.

The street layout was affected as a result of the decision taken on the plan to widen and straighten the original streets. According to this plan decision, Gökben Street (where Uçtum Mesjid is sited), Aydın Street, Oğuzlar Street and Kutlu Street were widened to 8 metres (Fig. 20a, b). Going against the plan, however, Gökben Street and Güngör Street were widened to 10 metres.

In parallel to the changes to the street layout, the original paving was covered with screed in 1987, in direct contravention of the regulation related to the conservation of the street characteristics in terms of their form, pavement and slopes.

New constructions were made not only on Kurtuluş Street, but also throughout the historical urban core and in the 3rd degree archaeological site. According to the regulations within the urban conservation and development plan, the four-storey high new buildings were constructed on Kurtuluş Street. They can be constructed next to registered buildings and damaging the
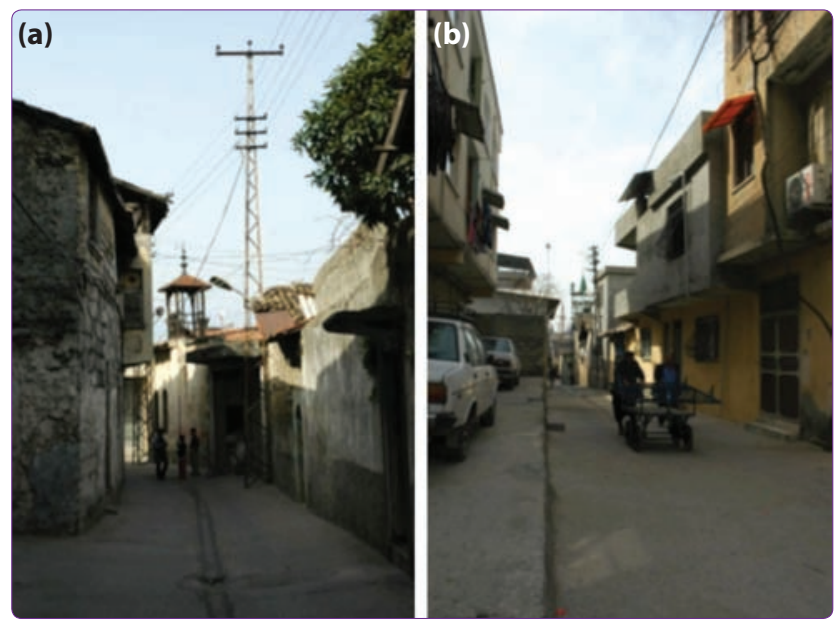

Figure 20. (a) Gökben Street with Uçtum Mesjid located on the corner (Photograph: Rifaioğlu, M.N., 2007) (b) Aydın Street (Photograph: Rifaioğlu, M.N., 2007). 

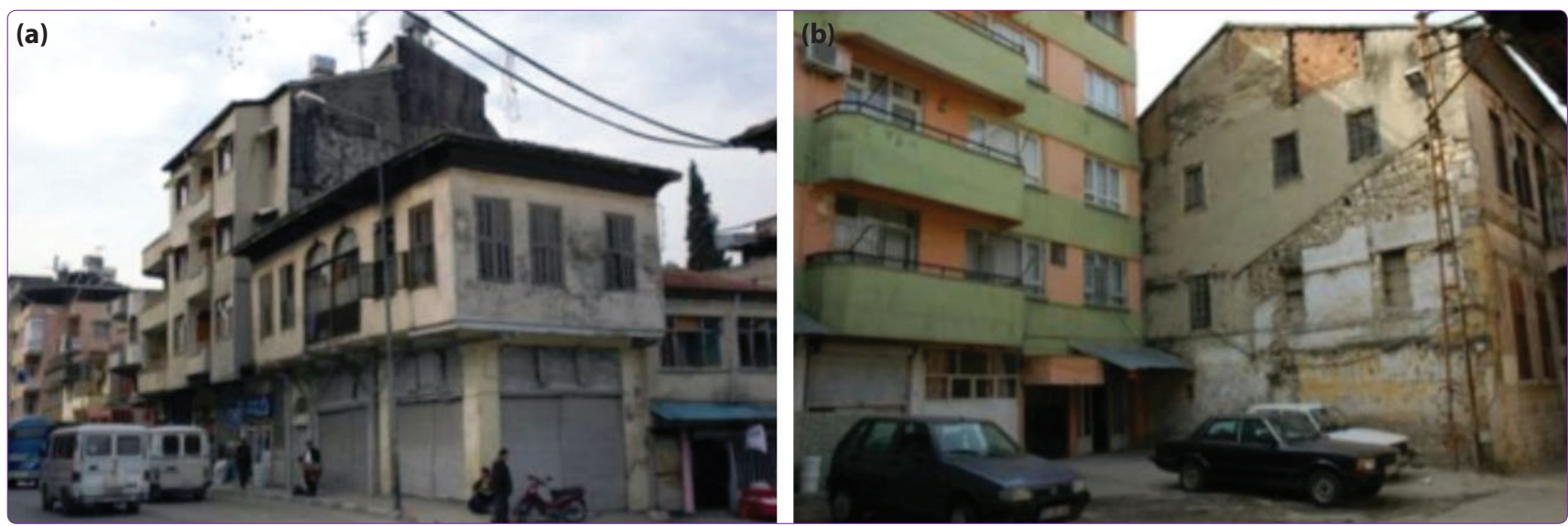

Figure 21. (a) A new building, constructed next to a registered building on Kurtuluş Street (Photograph: Rifaioğlu, M.N., 2007). (b) A new building constructed within the historical urban core (Photograph: Rifaioğlu, M.N., 2007).

original character of the street. Besides, many other new buildings were constructed within the historical urban core, thus altering its traditional residential character, which was also affected by their new architectural elements and reinforced concrete structures (Fig. 21a, b).

Although the 1987 plan stressed the importance of conserving the population of urban site, no precautions were taken regarding the legal status of the population, such as owners or tenants. In parallel to the contemporary needs and the newly emerging development areas in Antakya, the major users of the historical urban core were tenants rather than owners, and had a low level of education and a lower income level. As a consequence, the traditional residential houses were usually kept in a very poor condition, as the residents could not be held liable for the proper repair and maintenance of the houses; and inevitably, the houses were subjected to inappropriate and unconscious repairs by the tenants, resulting in a loss of original architectural elements and poor structural conditions. Besides this, many of the properties were left unoccupied, and thus they quickly became dilapidated and in need of urgent repair (Fig. 22a, b).

The tenant manufacturers, including shoemakers, timber workshops, etc. also used the houses very dilapidated conditions. Their use of equipment and chemicals damaged the buildings through overloading
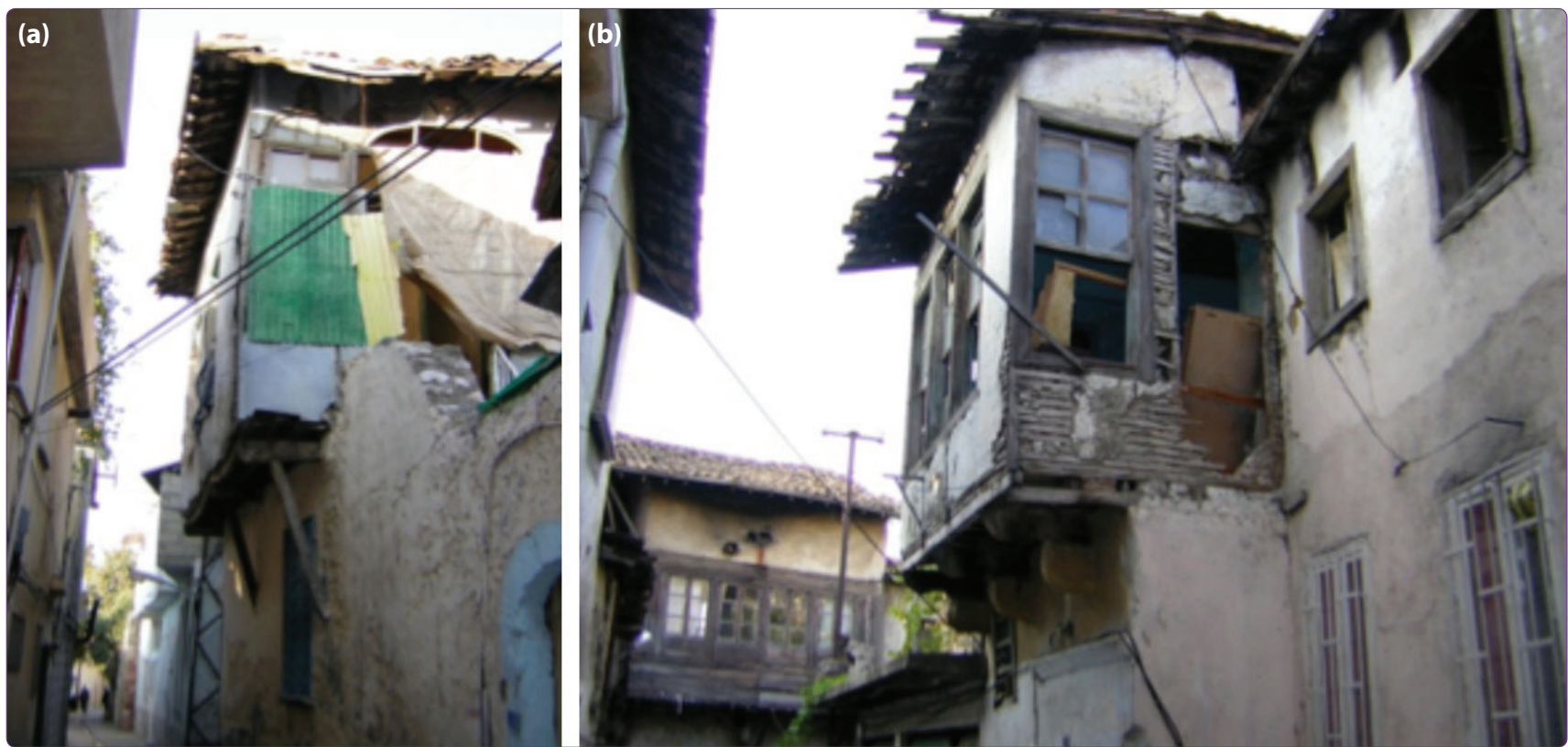

Figure 22. (a) A traditional house in Özdemir Street: An example of a personal attempt to repair an original window (Photograph: Rifaioğlu, M.N., 2005) (b) A deteriorated and vacant traditional house in Sokullu Street (Photograph: Rifaioğlu, M.N., 2005). 
to the detriment of the structure, defects and disruption to the original materials, disappearance of the original features of the building, and dense usage of the building in its spatial organization. They tended to prefer the traditional houses due to the low rents, despite the difficulties in access to the houses through the narrow streets.

In addition to inappropriate repairs and interventions that occurred within the historical urban core, a number of restoration projects were implemented after 2004 in line with the development of a conservation drive in Turkey. ${ }^{36}$ Nevertheless, the inappropriate functional interventions and/or insufficiency of the restoration projects caused deterioration not only at the scale of cultural property, but also on an urban scale as well.

Under these circumstances, a revision to the urban conservation and development plan was prepared and approved in 2009 that revised the conservation sites and their borders. It defined two archaeological sites, respectively 1st degree and 3rd degree archaeological sites. The 1st degree archaeological site covers four different areas within the planned area (Fig. 23). One of them, located to the north of the historical urban core near the Hacı Kuriş River, is currently area in use as a car-parking area. Another 1st degree archaeological site is located on the 3rd degree archaeological site where a tumulus existed. The west declivity of Habib Neccar Mountain is also registered as a 1st degree archaeological area. The north-east of the historical urban core is defined as a 1st degree archaeological site, at the site of St. Peter Grotto Church. There is currently in place a construction ban in all 1st degree archaeological sites.

A 3rd degree archaeological site is located in the north part of the historical urban core, where an industrial and commercial area existed after the 1957 urban development plan. The another 3rd degree archaeological site surrounds the urban site area, and it is also consisted the urban site impact zones.

The urban site has been revised and re-named as an urban-archaeological site, and now extends to the west bank of Asi River where a public park and a square were created in the French Mandate Period existed. The urban and 3rd degree archaeological site is created the historic urban core where total registered

\footnotetext{
${ }^{36}$ Şahin Güçhan, N., E. Kurul, 2009. "A History of the Development of Conservation Measures in Turkey: From the Mid 19th Century until 2004", METU Journal of the Faculty of Architecture, Volume 26:2, METU, Ankara, pp:19-44.
}

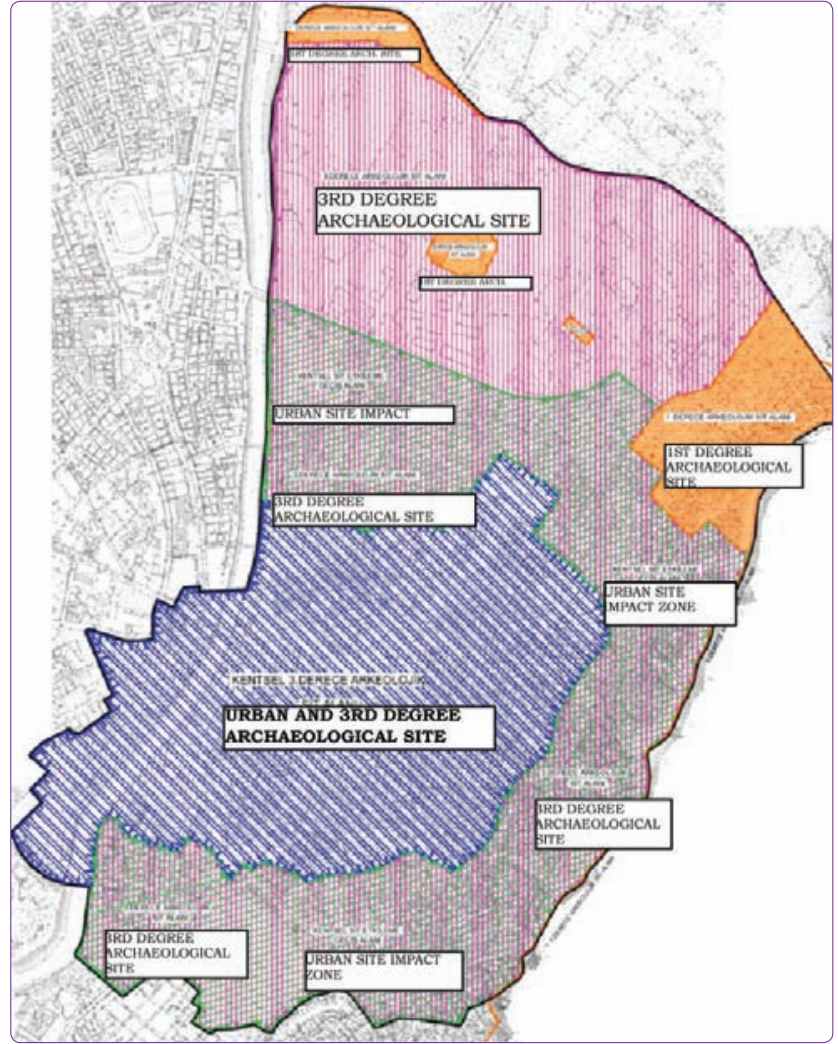

Figure 23. The revised site boundaries in the revised urban conservation and development plan, 2009 (Source: Antakya Municipality).

buildings existed within the site border. The entire 3rd degree archaeological site is also registered as an urban site impact zone.

The plan stresses that the volume of vehicular traffic and the lack of car-parks are a significant problem within the historical urban core, and so new roads and car-parks are suggested in the plan. A new 22 me tre and 32 metre road has been proposed on the west side of the historical urban core, running parallel to Kurtuluş Street.

Five multi-storey car parks are planned for the historical urban core, two of which are located on Kurtuluş Street, and the others on the new 22-metre road. The plan proposes the construction of a $5.5 \mathrm{~km}$ mono-rail through the historical urban core, as well as a cable car, which is to run from next to the Şeyh Ali Mosque and rise to Mount Habib Neccar, where there are many archaeological edifices.

The plan proposes eight special project areas, which are: 1) Urban Transformation Area; 2) Culture Park; 3) Municipality Square; 4) Republic Square; 5) Long Bazaar; 6) Habib Neccar Mosque and Square; 7) Light Industrial Zone; and 8) Zenginler District (Fig. 24). 


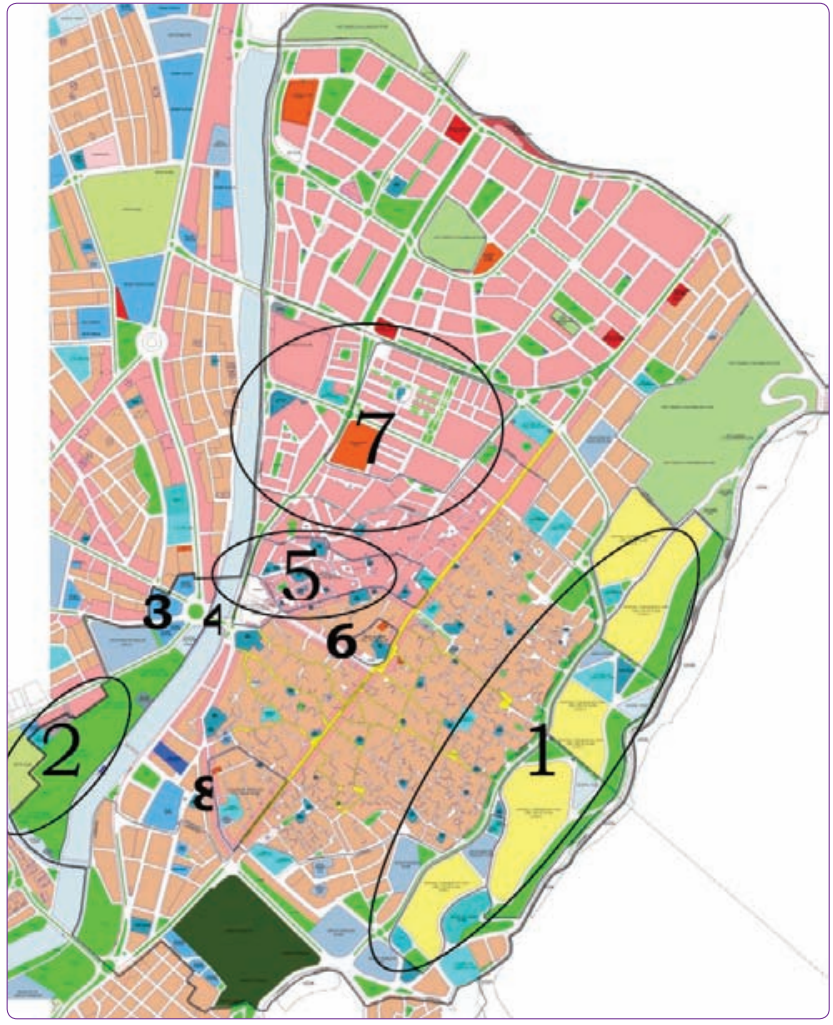

Figure 24. Special Project Areas (Source: Antakya Municipality).

\section{1- Urban Transformation Area}

The urban transformation area is located on the west side of the historical urban core, and covers an area of $220,146 \mathrm{~m}^{2}$. The plan proposes the construction of prestigious houses, for which expropriations will be made, with the current inhabitants of the area decanted to the new development areas.

\section{2- Culture Park}

This special project area is located on the west side of Asi River, currently the site of the largest public park in Antakya. The plan proposes the development of social and cultural facilities within the park, and the reconstruction of the Roman Bridge and Nauras along the Asi River.

\section{3- Municipality Square}

Municipality Square was formed in the French Mandate Period, and today it contains 10 registered public buildings. The plan proposed the registered buildings be turned into social and cultural facilities, and accordingly the Cine Empire and the Parliamentary building of the Hatay Government were converted into a multipurpose hall for the city of Antakya.

\section{4- Republic Square}

The Republic Square was formed after the 1957 ur- ban development plan. Today, there are religious, commercial and gastronomic facilities around the square, which the plan stresses should remain.

\section{5- Long Bazaar-Uzunçarşı}

The Long Bazaar is the traditional commercial zone of Antakya, containing arasta (specialized souqs), khans, bedesten (covered bazaar), mosques, baths, traditional soap factories, and traditional buildings and fountains (Fig 25). The plan proposes interventions to the facades and roofs of the traditional commercial units.

\section{6- Habibi Neccar Mosque and Square}

There is no clear definition in the scope of the special project for the Habib Neccar Mosque and Square, the only aspect being mentioned is that it is an important place, and thus requires a very special conservation project that takes in also its surroundings.

\section{7- Light Industrial Zone}

This zone is located to the north of the historical urban core, and is registered as a 3rd degree archaeological site. It contains light industrial workshops, a wholesale market hall and an old coach station (Fig. 26). The plan proposes to inject social and cultural activities and touristic functions into the zone to create a link between traditional urban fabric and this area.

\section{8- Zenginler District}

The Zenginler district contains mainly traditional houses and French Mandate Period buildings. The plan proposes the development of this district into an area for touristic purposes, for which a functional transformation is encouraged. To date, two traditional
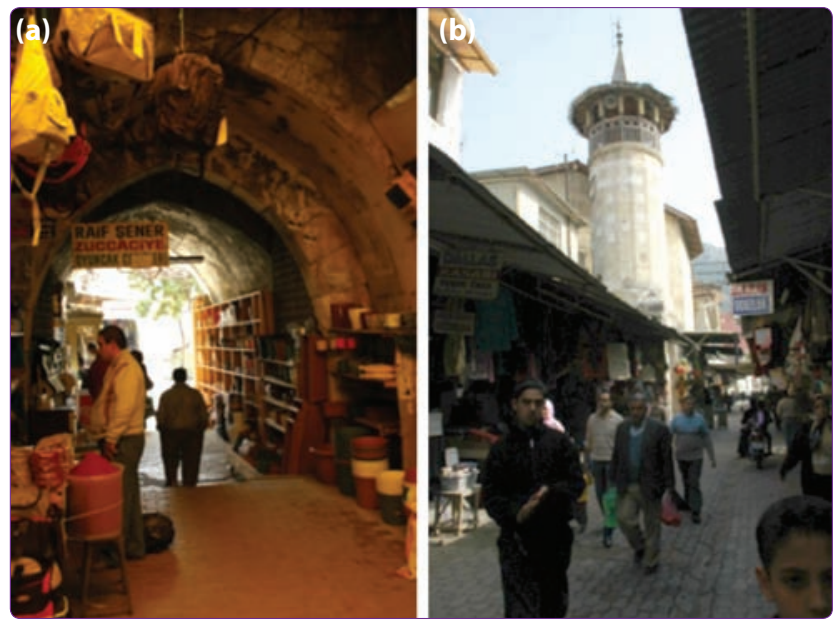

Figure 25. (a) The entrance of Kurşunlu Khan placed on the Long Bazaar (b) The Long Bazaar of Antakya, (Photograph: Rifaioğlu, M.N., 2010). 


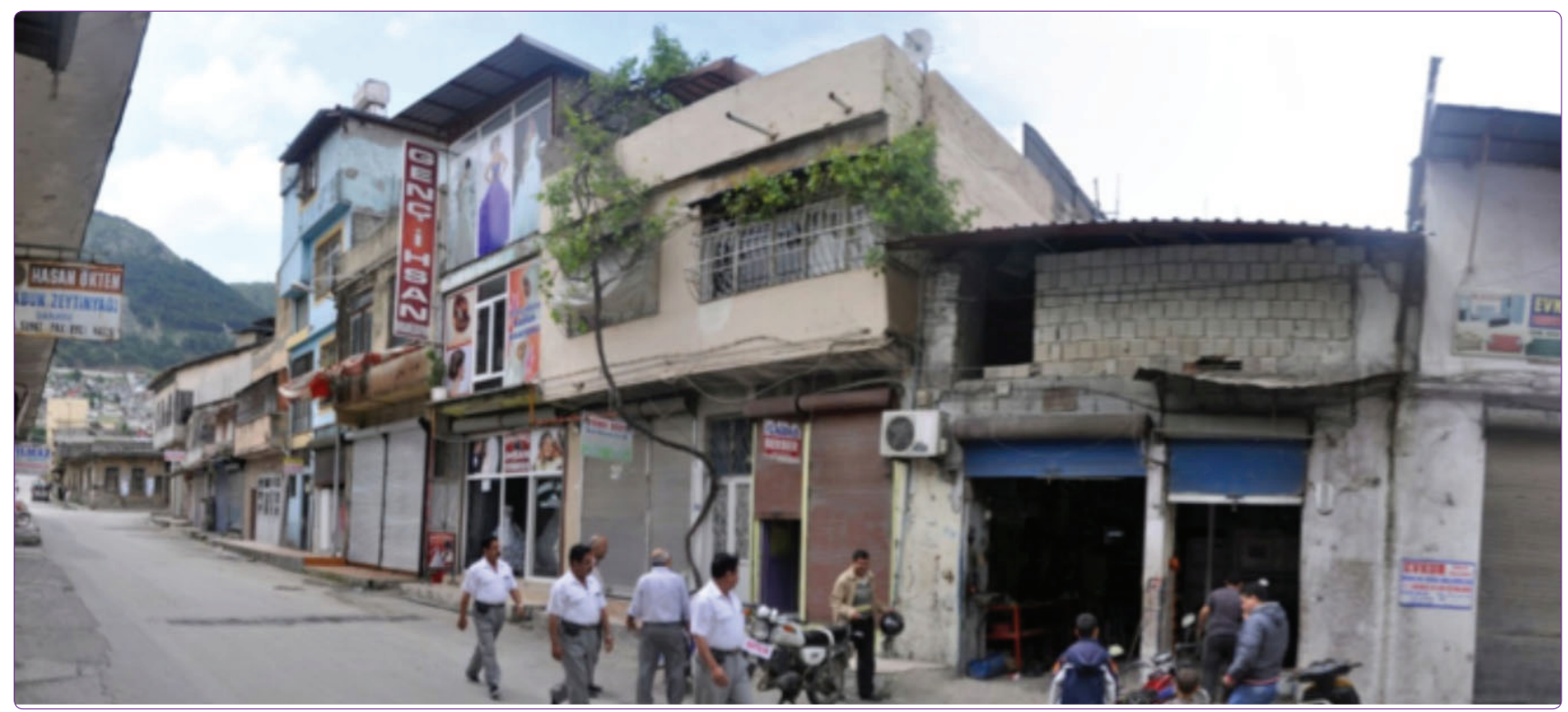

Figure 26. (a) The light industrial workshops (Photograph: Rifaioğlu, M.N., 2010).

buildings have been converted into hotels, and many traditional houses have been converted into cafes and shops.

\section{Concluding Remarks}

This historical analysis of urban development and conservation issue of Antakya has provided evidence that Antakya has undergone much transformation since the Hellenistic Period, and that the historical urban fabric faced different development strategies and implementations from the Ottoman period onwards.

During the period of the French Mandate, the city was much affected by the development strategies. The first development plan for Antakya was prepared by Réne Danger, after which the development strategies targeted development related to tourism, archaeology and orientalism. Many construction programmes were launched in line with the goal of the development strategies. In particular, the Danger plan proposed a new urban street network and the connection of the two sides of Asi River through the construction of new roads and bridges. A new wide street layout was proposed for the historical urban core of Antakya, passing from the western declivity of Mount Habib Neccar and looping from the northern part of the historical urban core. The city, being famous for its archaeological history, saw many excavations by American and French archaeologists, and an Archaeological Museum was constructed, in particular to house the Roman Mosaics that had been uncovered. This period lasted until 1939, after which the city became the last city to be united with the Turkish Republic.
During the Turkish Republican period, different development and conservation plans were prepared in 1948, 1957, 1978, 1987 and 2009. An overall evaluation of these plans reveals that the planning decisions did much to change the character of the historical urban core, with proposals for new streets; the expropriation of original plots to make way for straighter and wider streets within the organic street layout; new and incompatible intervention principles for the original character of the historical urban core; inappropriate development strategies on the original historical urban morphology; proposals for new and inharmonious functional injections through the urban context; and so forth.

Additionally, the urban conservation and development plans were insufficiently prepared, and treated historical Antakya only as an organic, and somehow chaotic physical entity that was in need of regular urban organisations and contemporary interventions. Accordingly, new functional interventions have been proposed and implemented, both in the historical urban core and in the traditional residential and commercial zones.

While the development plans both in French Mandate Period and in Turkish Republican period attempted to apply a new infrastructure to the traditional fabric, physically and socially, the historical urban core suffered many destructions and deformations over time.

New vehicular and pedestrian accesses have been proposed and new squares planned, for which many 
expropriations and unifications occurred within the urban core so as to achieve the physical interventions of the development plans.

Additionally, these planning decisions and interventions resulted in changes to the original cadastral pattern of the historical urban core. Strikingly, the number of plots registered in the city increased from 7,000 in 1929 to 10,000 in 2009 as a result of divisions of plots, and appropriations of agricultural areas and Christian and Muslim cemeteries. Therefore, as a result of the development plans, the original land-use pattern has changed, creating new residential and industrial areas.

According to the revised urban conservation and development plan (UCDP) prepared in 2009, the ratio of residential area into historic urban fabric is to be decreased from the 1987 UCDP levels; whereas the ratios of commercial facilities, tourism facilities and municipality services, such as multi-story car-parking areas, are to be increased. Additionally, an urban transformation area has been defined in the revised UCDP that will affect $5.11 \%$ of the total historical urban fabric, which is a considerable proportion of the traditional residential zone, itself accounting for only $19.03 \%$ of the total.

Consequently, the decisions taken in spite of the long and diverse history of Antakya would appear to have turned the city into a stranger. Historical Antakya was not formed according to computational parameters, or with profitable development strategies in mind, but rather according to special codes and rules under different periods.

As a result of this the historical urban core of Antakya is now suffering an amnesia that penetrates to its very roots in all aspects: topographical, physical, socio-cultural, geographical, and the experiences of the original inhabitants.

\section{References}

1. A. Demir, Through the Ages Antakya (Akbank Publications, İstanbul, 1996).

2. A.F. Türkmen, Mufassal Hatay (İstanbul Cumhuriyet Matbaası, 1937).
3. C. O'Connor, Roman Bridges (Cambridge University Press, Cambridge, 1993).

4. C. Kondoleon, Antioch: The Lost Ancient City (Princeton University Press, 2001).

5. E.S. Bouchier, A Short History of Antioch, 300 B.C. - A.D. 1268 (Blackwell, Oxford, 1921).

6. G. Downey, A History of Antioch in Syria: From Seleucus to the Arab Conquest (Princeton University Press, 1961).

7. G. Downey, Ancient Antioch (Princeton University, 1963).

8. GEEAYK, Antakya Kültür Envanteri, (1975).

9. G. Özdeş, Antakya Urban Development Plan,(1957).

10. Hatay Valiliği, Hatay Kültür Envanteri, (2011).

11. I. Aslanoğlu, 'Fransız İşgal ve Manda Döneminde İskenderun Sancağı: Kentsel ve Mimari Değişimleriyle İskenderun, Antakya ve Kırıkhan Kazaları'. Papers Submitted to International Symposium Ottoman Heritage in the Middle East, vol. 1, Publication of Atatürk Culture Center, Ankara, (2000).

12.J. Weulersse, 'Antioche Essai de géographie urbaine', Bulletin d'Etudes Orientales, Tome IV, (1934).

13. M. Tekin, Antakya Tarihinden Yapraklar ve Halefzade Süreyya Bey (Antakya, 1993)

14. M. Tekin, Hatay Tarihi Osmanlı Dönemi, Atatürk Kültür Merkezi Başkanlığı Yayınları (Ankara, 2000)

15. N. Şahin Güçhan,, E. Kurul, 2009. "A History of the Development of Conservation Measures in Turkey: From the Mid 19th Century until 2004", METU Journal of the Faculty of Architecture, Volume 26:2, METU, Ankara, pp:19-44.

16. P. Jacquot, Antioche: Centre de Tourisme, Comite de Tourisme d'Antioche (Antakya, 1931).

17. P. Pinon, 'Survivances Et Transformations Dans La Topographie D'Antioche Apres L'Antiquite'. Topoi, Suppl. 5 (2004), pp. 191-219.

18. R. Özdemir, 'Osmanlı Döneminde Antakya'nın Fiziki ve Demografik Yapısı 1709-1860'. Belleten, 221 (1994).

19. Ü.F. Açıkgöz, A Case in French Colonial Politics of Architecture and Urbanism: Antioch and Alexandretta During the Mandate, (un-published Master Thesis, METU-Faculty of Architecture, Ankara, 2008).

20.V. Pinto, L'Evolution de Antioche, son passé, son état actuel, son avenir (un-published Master thesis, Institue d'Urbanisme de Paris, Paris, 1938).

Key words: Antakya historic urban core; French mandate; Turkish Republic; urban conservation; urban development.

Anahtar sözcükler: Antakya tarihi kent dokusu; Fransız mandası; Türkiye Cunhuriyeti; kentsel koruma; imâr. 